Phenolic and Triterpene Glycosides from the Stems of Ilex litseaefolia

\author{
Ai-Lian Zhang, ${ }^{\dagger, \star}$ Qi Ye,${ }^{\dagger}$ Bo-Gang Li, ${ }^{\dagger}$ Hua-Yi Qi,${ }^{\dagger}$ and Guo-Lin Zhang $*,{ }^{\dagger}$ \\ ${ }^{\dagger}$ Chengdu Institute of Biology, Chinese Academy of Sciences, Chengdu 610041, People’s Republic \\ of China \\ ${ }^{\ddagger}$ Chengdu Institute of Organic Chemistry, Chinese Academy of Sciences, Chengdu 610041, People’s \\ Republic of China
}

\title{
Supportion Information
}

S1. Selected HMBC correlations $(\rightarrow)$ and NOESY $(\leftrightarrow)$ of compounds 1-6

S2. HRESIMS of Litseaefoloside A (1)

S3. ESIMS of Litseaefoloside A (1)

S4. ${ }^{1} \mathrm{H}$ NMR $\left(\mathrm{CD}_{3} \mathrm{OD}, 600 \mathrm{MHz}\right)$ Spectrum of Litseaefoloside A (1)

S5. ${ }^{13} \mathrm{C}$ NMR $\left(\mathrm{CD}_{3} \mathrm{OD}, 150 \mathrm{MHz}\right)$ Spectrum of Litseaefoloside A (1)

S6. HSQC Spectrum of Litseaefoloside A (1)

S7. HMBC Spectrum of Litseaefoloside A (1)

S8. NOESY Spectrum of Litseaefoloside A (1)

S9. HRESIMS of Litseaefoloside B (2)

S10. ESIMS of Litseaefoloside B (2)

S11. ${ }^{1} \mathrm{H}$ NMR $\left(\mathrm{CD}_{3} \mathrm{OD}, 600 \mathrm{MHz}\right)$ Spectrum of Litseaefoloside B (2)

S12. ${ }^{13} \mathrm{C}$ NMR $\left(\mathrm{CD}_{3} \mathrm{OD}, 150 \mathrm{MHz}\right)$ Spectrum of Litseaefoloside B (2)

S13. HSQC Spectrum of Litseaefoloside B (2)

S14. HMBC Spectrum of Litseaefoloside B (2)

S15. NOESY Spectrum of Litseaefoloside B (2)

S16. HRESIMS of Litseaefoloside C (3)

S17. ESIMS of Litseaefoloside C (3)

S18. ${ }^{1} \mathrm{H}$ NMR $\left(\mathrm{CD}_{3} \mathrm{OD}, 600 \mathrm{MHz}\right)$ Spectrum of Litseaefoloside C (3)

S19. ${ }^{13} \mathrm{C}$ NMR $\left(\mathrm{CD}_{3} \mathrm{OD}, 150 \mathrm{MHz}\right)$ Spectrum of Litseaefoloside $\mathrm{C}(3)$ 
S20. HSQC Spectrum of Litseaefoloside C (3)

S21. HMBC Spectrum of Litseaefoloside C (3)

S22. NOESY Spectrum of Litseaefoloside C (3)

S23. HRESIMS of Litseaefoloside D (4)

S24. ESIMS of Litseaefoloside D (4)

S25. ${ }^{1} \mathrm{H}$ NMR $\left(\mathrm{CD}_{3} \mathrm{OD}, 600 \mathrm{MHz}\right)$ Spectrum of Litseaefoloside D (4)

S26. ${ }^{13} \mathrm{C}$ NMR $\left(\mathrm{CD}_{3} \mathrm{OD}, 150 \mathrm{MHz}\right)$ Spectrum of Litseaefoloside D (4)

S27. HSQC Spectrum of Litseaefoloside D (4)

S28. HMBC Spectrum of Litseaefoloside D (4)

S29. NOESY Spectrum of Litseaefoloside D (4)

S30. HRESIMS of Spathodic acid 28-O- $\beta$-D-glucopyranoside (5)

S31. ESIMS of Spathodic acid 28-O- $\beta$-D-glucopyranoside (5)

S32. ${ }^{1} \mathrm{H}$ NMR $\left(\mathrm{C}_{5} \mathrm{D}_{5} \mathrm{~N}, 600 \mathrm{MHz}\right)$ Spectrum of Spathodic acid 28-O- $\beta$-D-glucopyranoside (5)

S33. ${ }^{13} \mathrm{C}$ NMR $\left(\mathrm{C}_{5} \mathrm{D}_{5} \mathrm{~N}, 150 \mathrm{MHz}\right)$ Spectrum of Spathodic acid 28-O- $\beta$-D-glucopyranoside (5)

S34. HSQC Spectrum of Spathodic acid 28-O- $\beta$-D-glucopyranoside (5)

S35. HMBC Spectrum of Spathodic acid 28-O- $\beta$-D-glucopyranoside (5)

S36. NOESY Spectrum of Spathodic acid 28-O- $\beta$-D-glucopyranoside (5)

S37. HRESIMS of (20S)-Niga-ichigoside F1 (6)

S38. ESIMS of (20S)-Niga-ichigoside F1 (6)

S39. ${ }^{1} \mathrm{H}$ NMR $\left(\mathrm{C}_{5} \mathrm{D}_{5} \mathrm{~N}, 600 \mathrm{MHz}\right)$ Spectrum of (20S)-Niga-ichigoside F1 (6)

S40. ${ }^{13} \mathrm{C}$ NMR $\left(\mathrm{C}_{5} \mathrm{D}_{5} \mathrm{~N}, 150 \mathrm{MHz}\right)$ Spectrum of (20S)-Niga-ichigoside F1 (6)

S41. HSQC Spectrum of (20S)-Niga-ichigoside F1 (6)

S42. HMBC Spectrum of (20S)-Niga-ichigoside F1 (6)

S43. NOESY Spectrum of (20S)-Niga-ichigoside F1 (6) 
S1. Selected HMBC correlations $(\rightarrow)$ and NOESY $(\leftrightarrow)$ of compounds 1-6
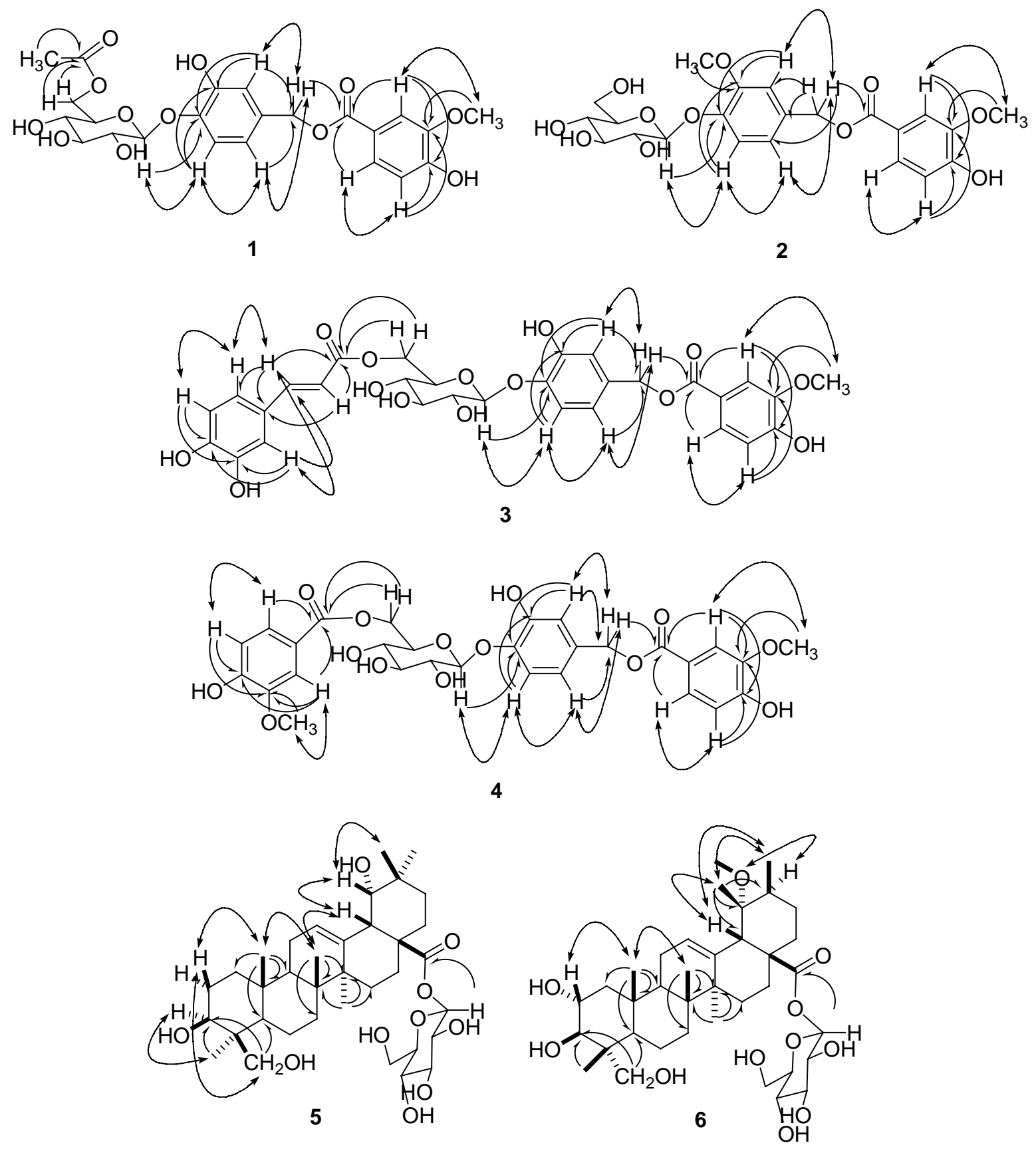
S2. HRESIMS of Litseaefoloside A (1)

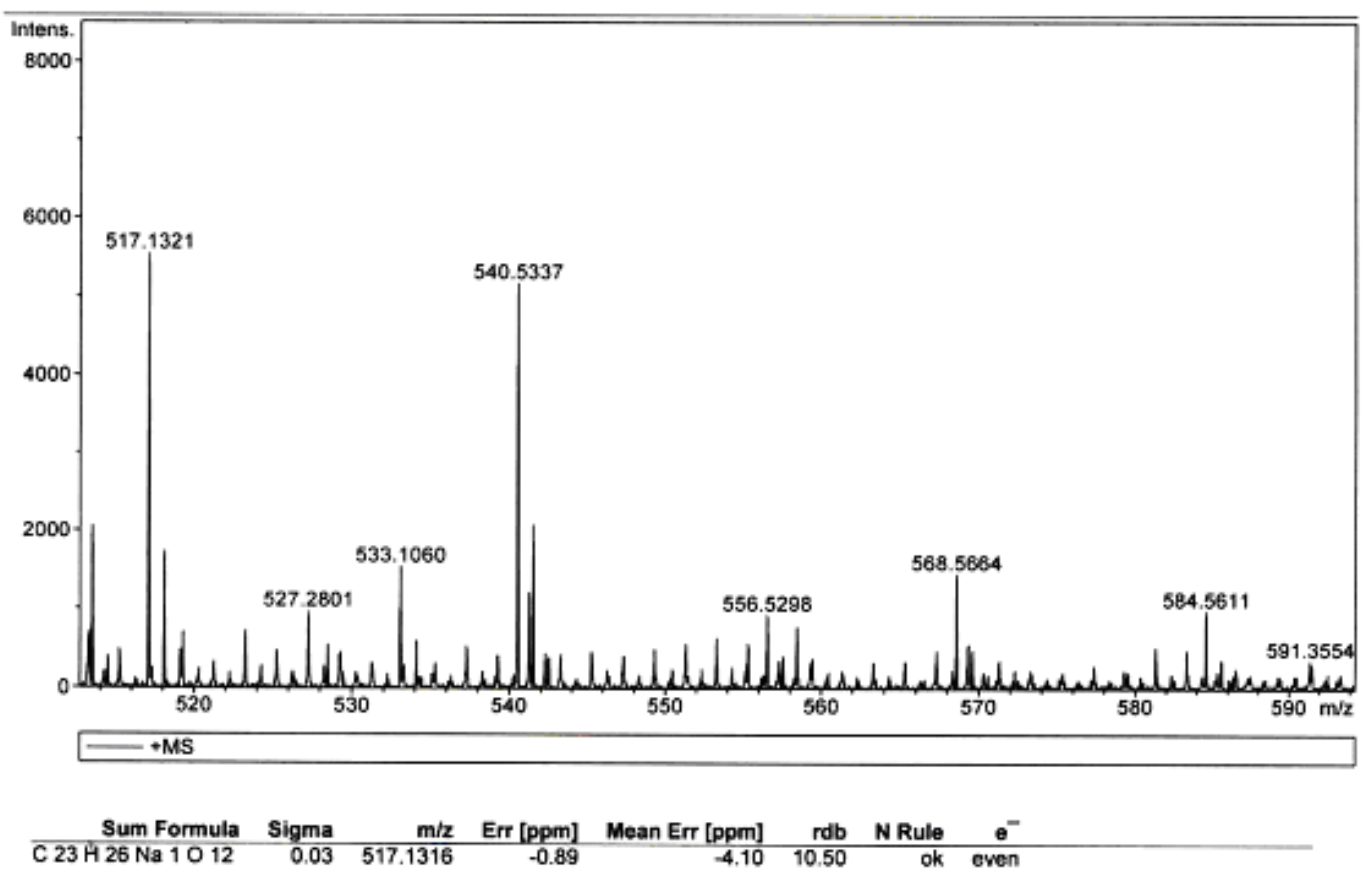

S3. ESIMS of Litseaefoloside A (1)

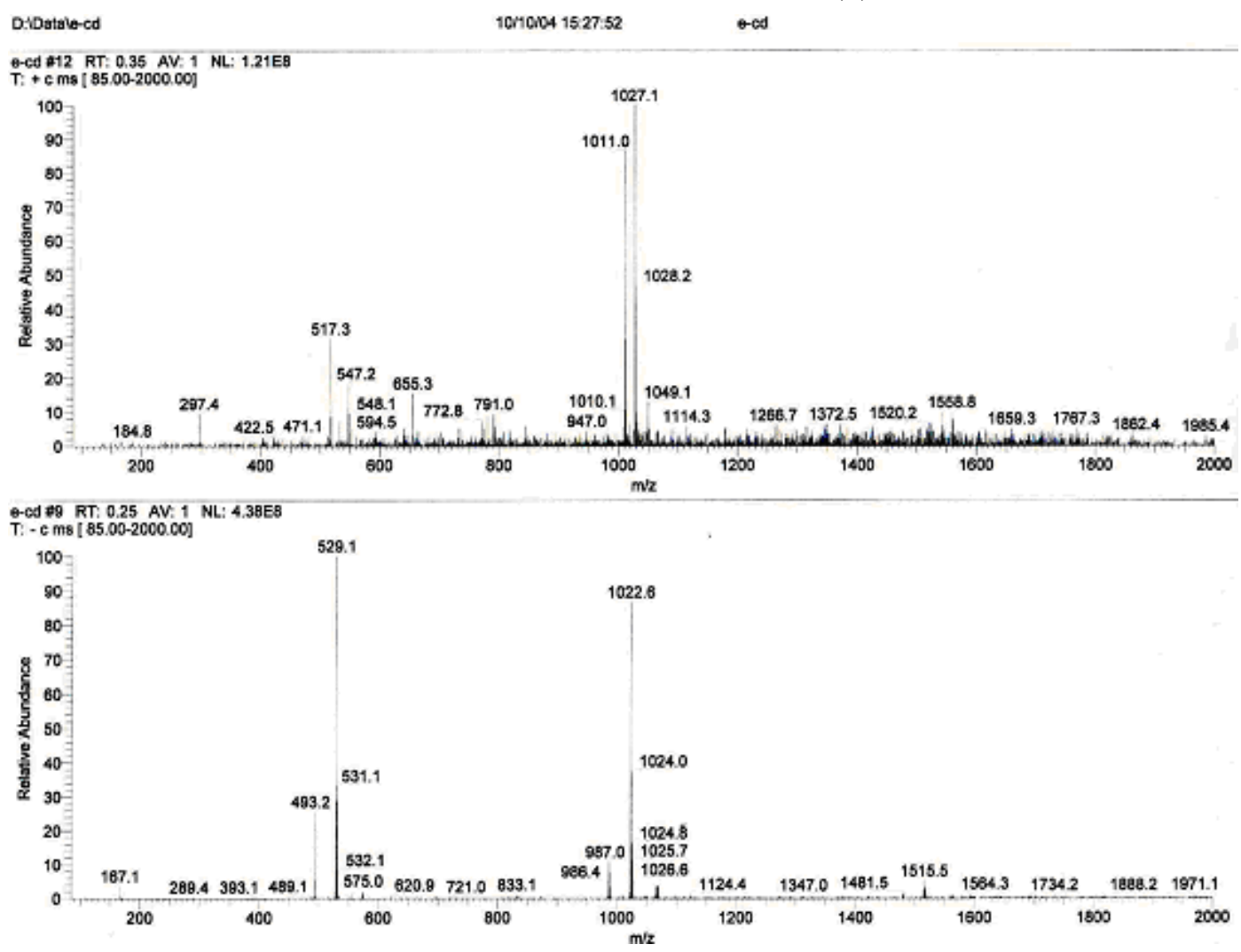


S4. ${ }^{1} \mathrm{H}$ NMR ( $\left.\mathrm{CD}_{3} \mathrm{OD}, 600 \mathrm{MHz}\right)$ Spectrum of Litseaefoloside A (1)

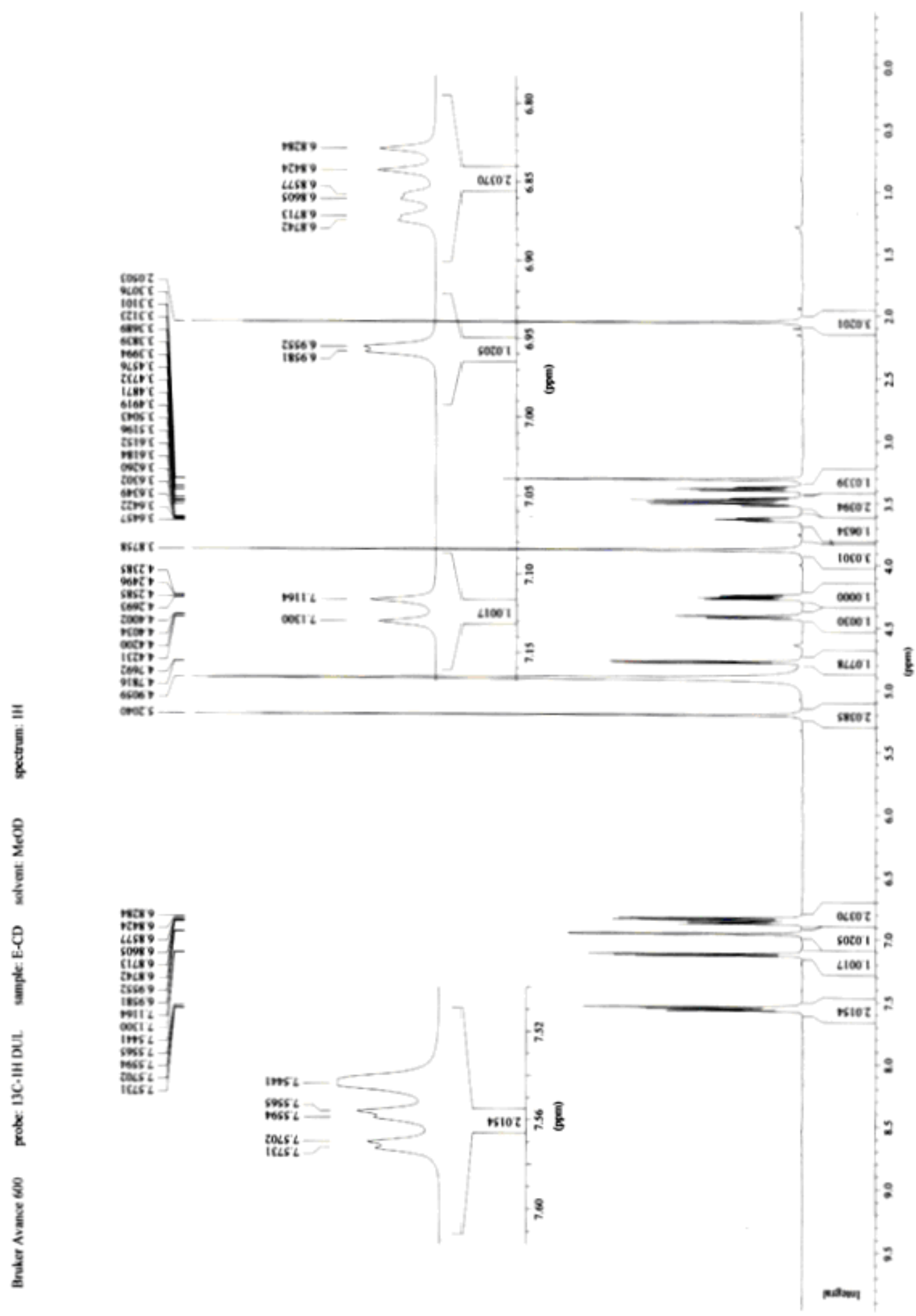


S5. ${ }^{13} \mathrm{C}$ NMR $\left(\mathrm{CD}_{3} \mathrm{OD}, 150 \mathrm{MHz}\right)$ Spectrum of Litseaefoloside A (1)

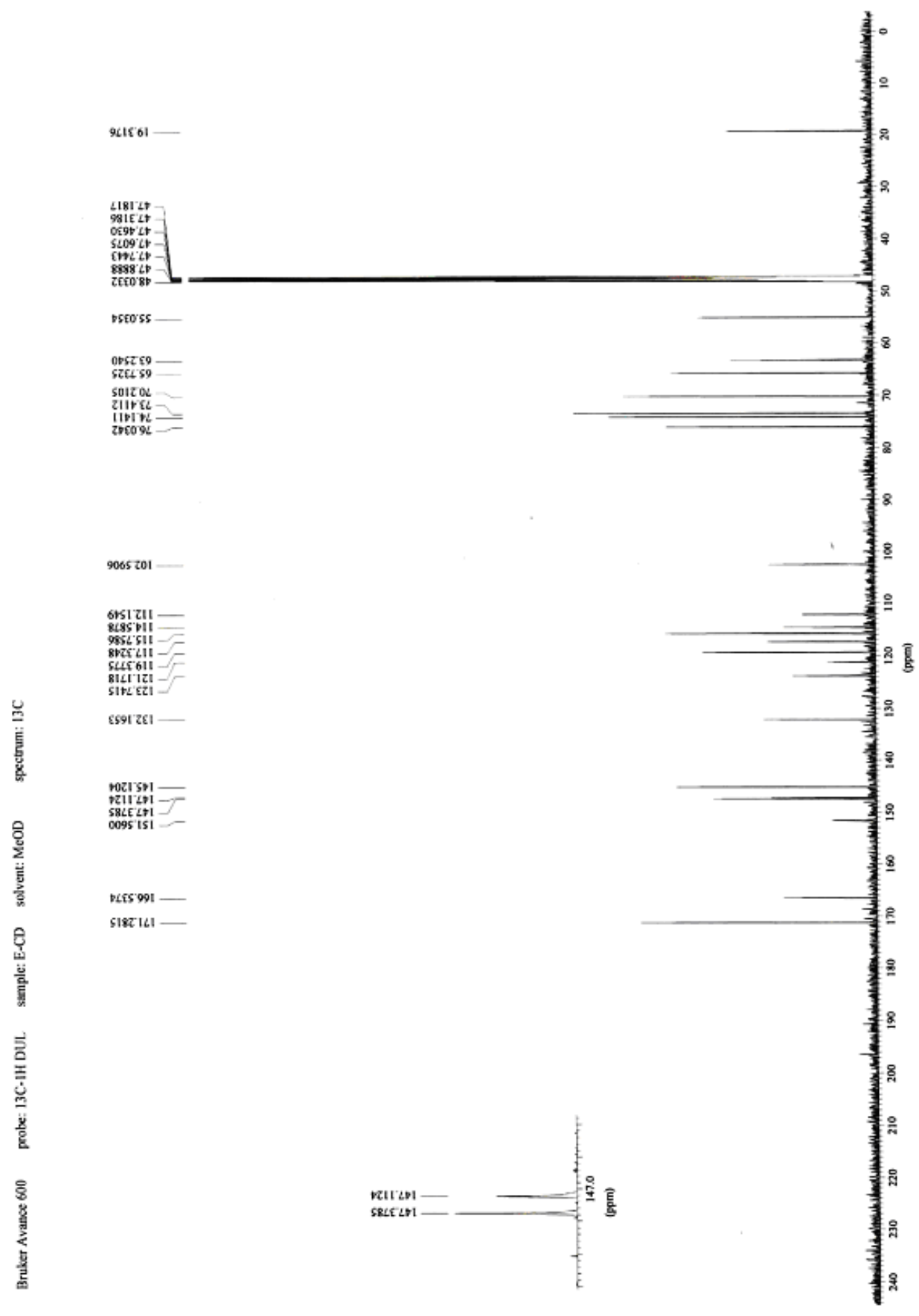


S6. HSQC Spectrum of Litseaefoloside A (1)

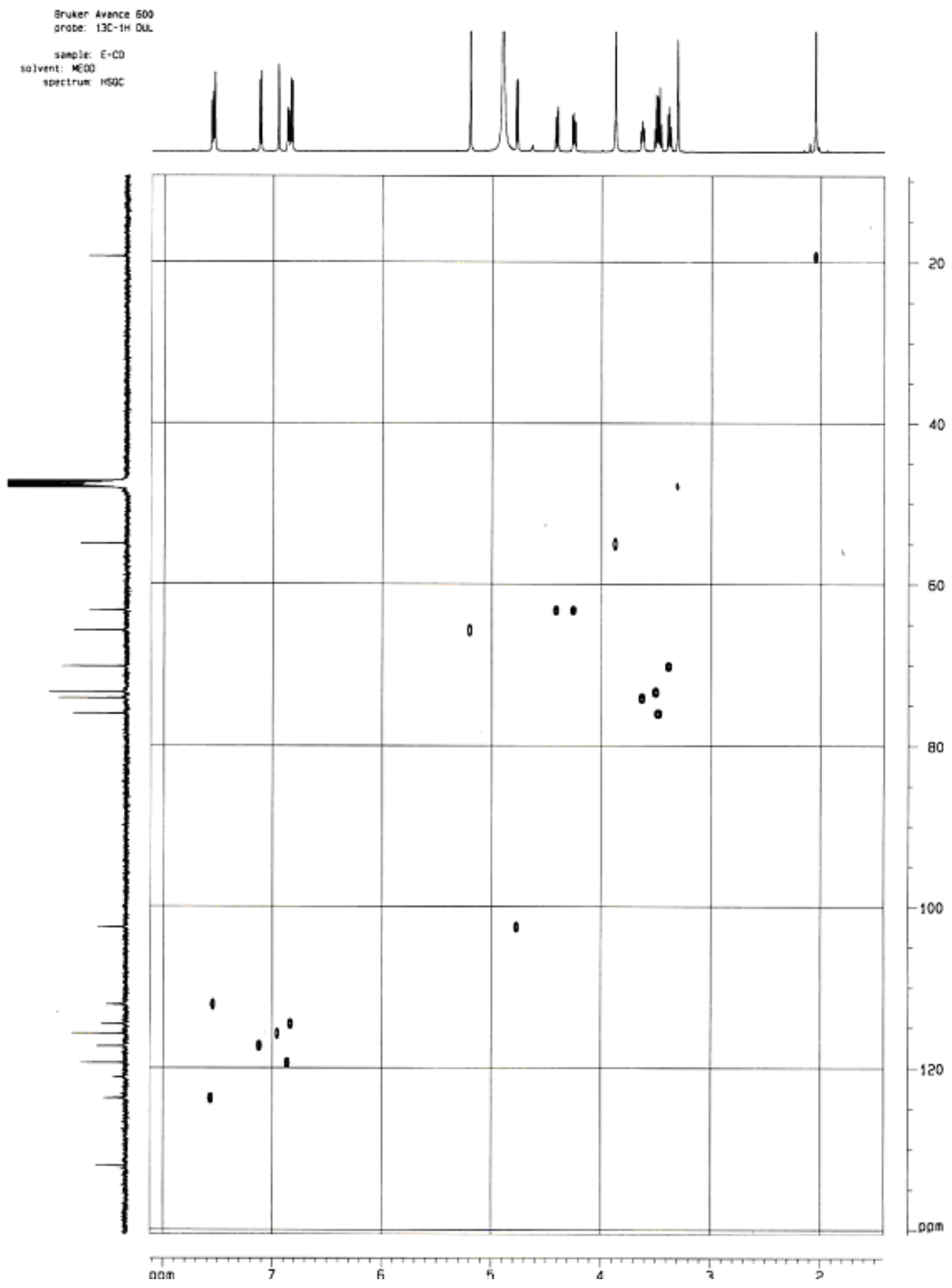


S7. HMBC Spectrum of Litseaefoloside A (1)

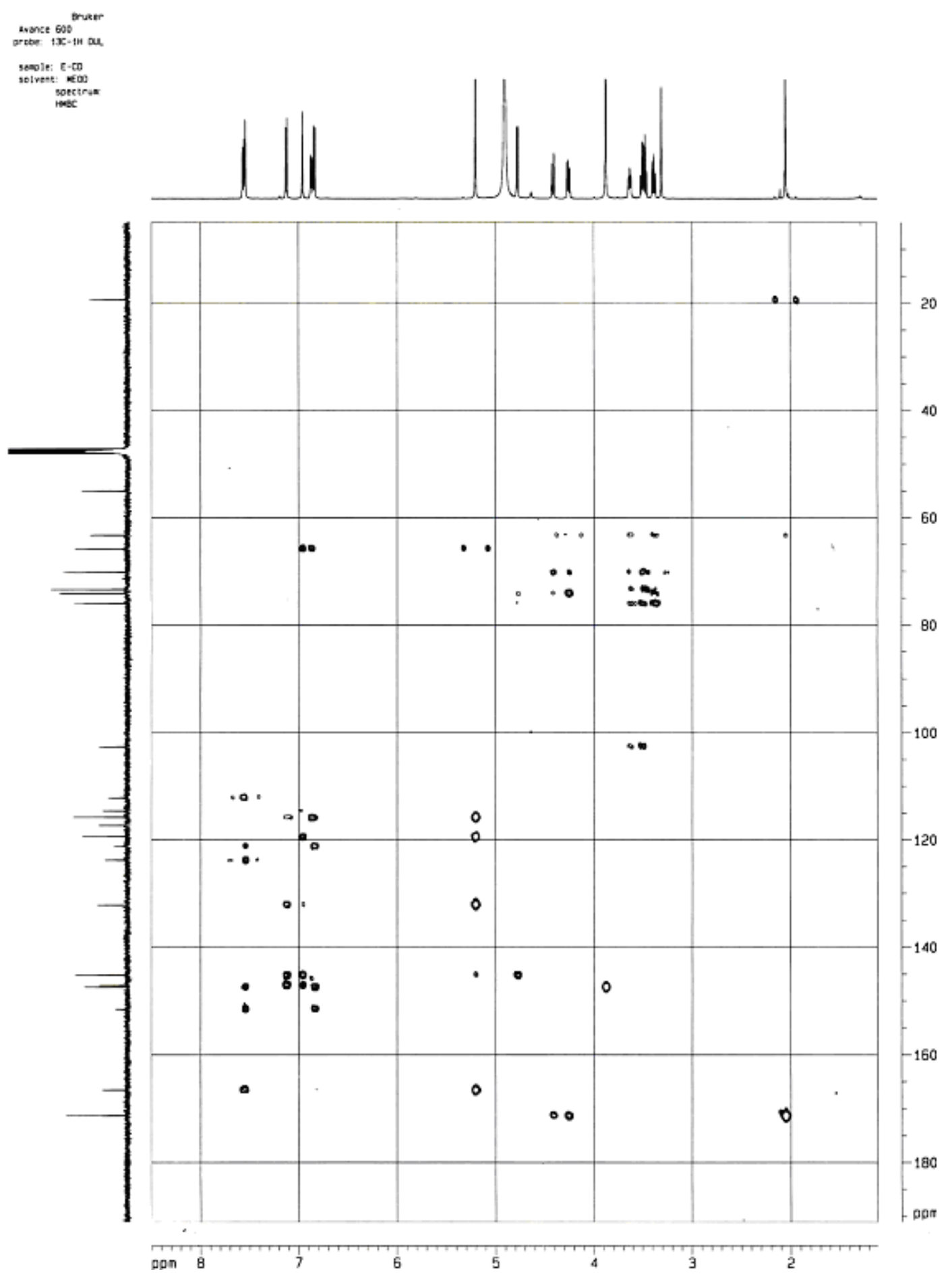


S8. NOESY Spectrum of Litseaefoloside A (1)
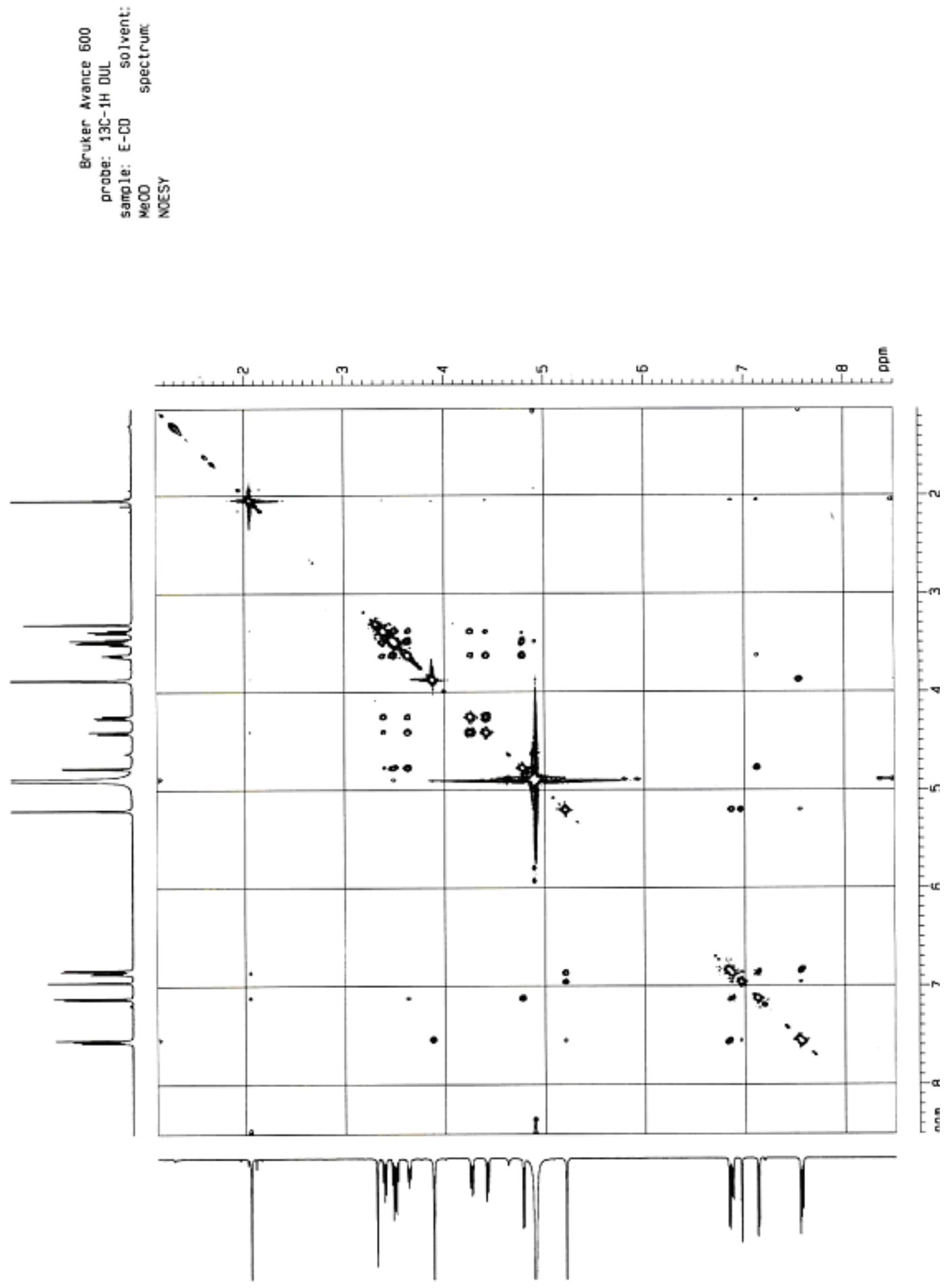
S9. HRESIMS of Litseaefoloside B (2)

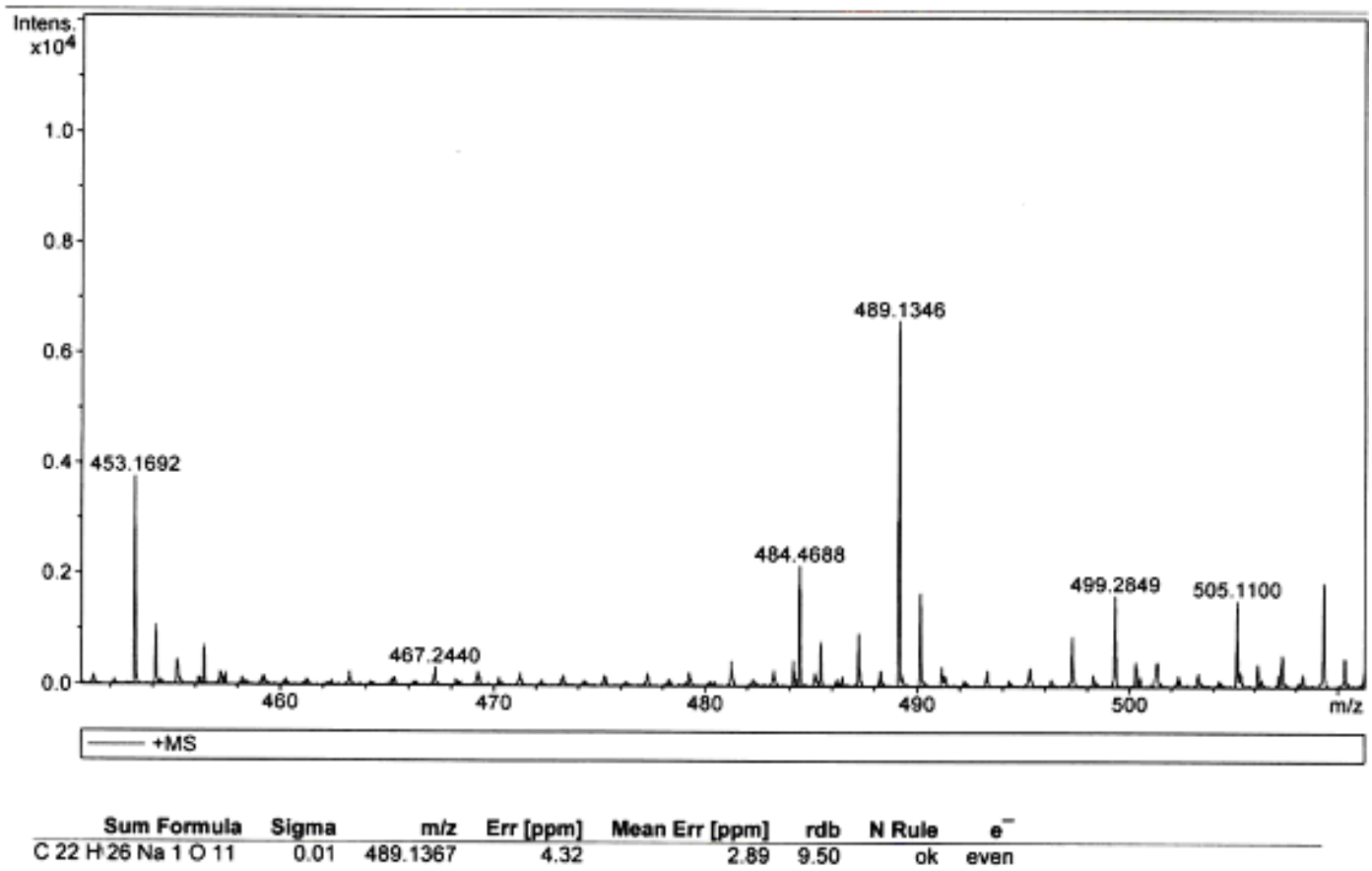

S10. ESIMS of Litseaefoloside B (2)

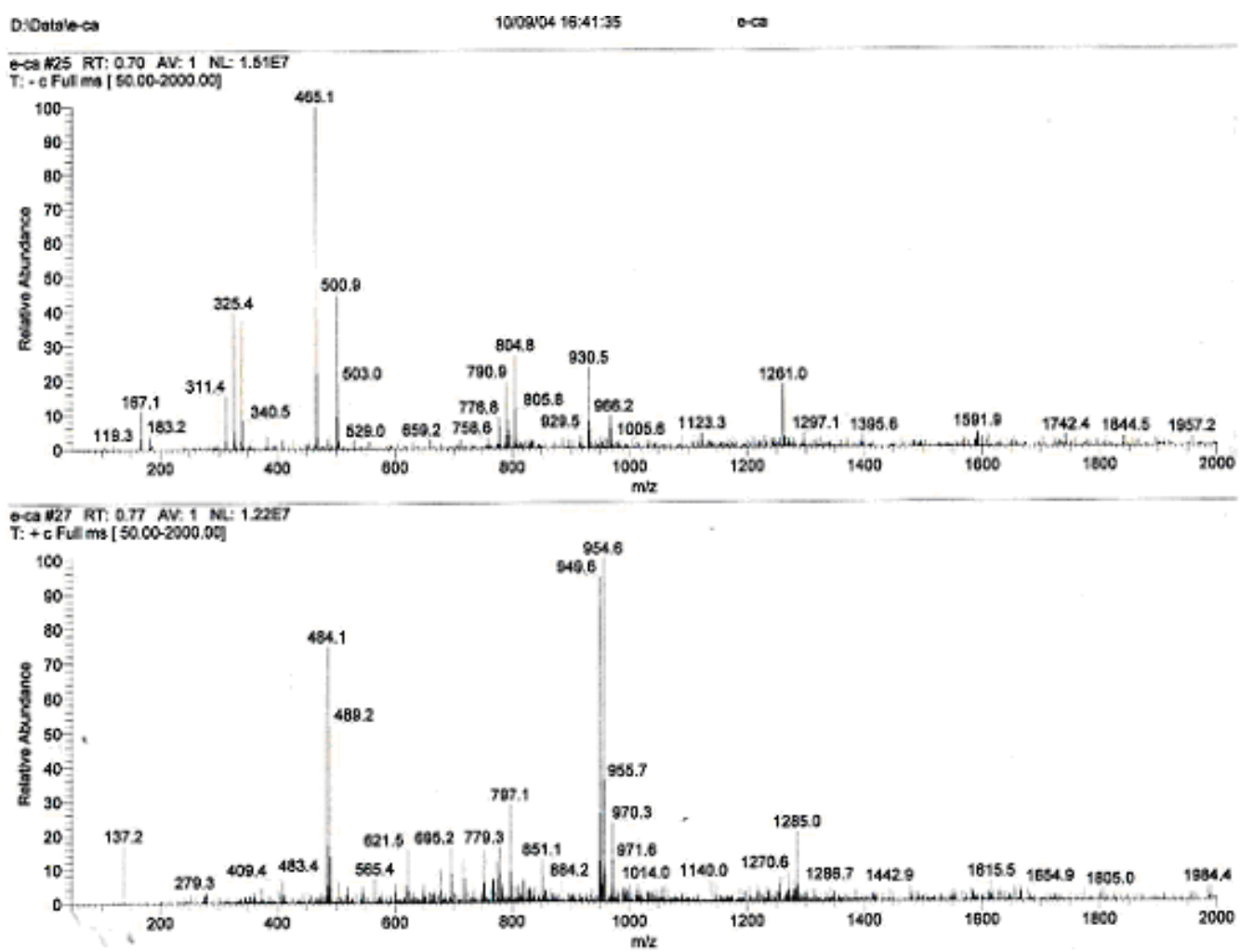


S11. ${ }^{1} \mathrm{H}$ NMR $\left(\mathrm{CD}_{3} \mathrm{OD}, 600 \mathrm{MHz}\right)$ Spectrum of Litseaefoloside B (2)

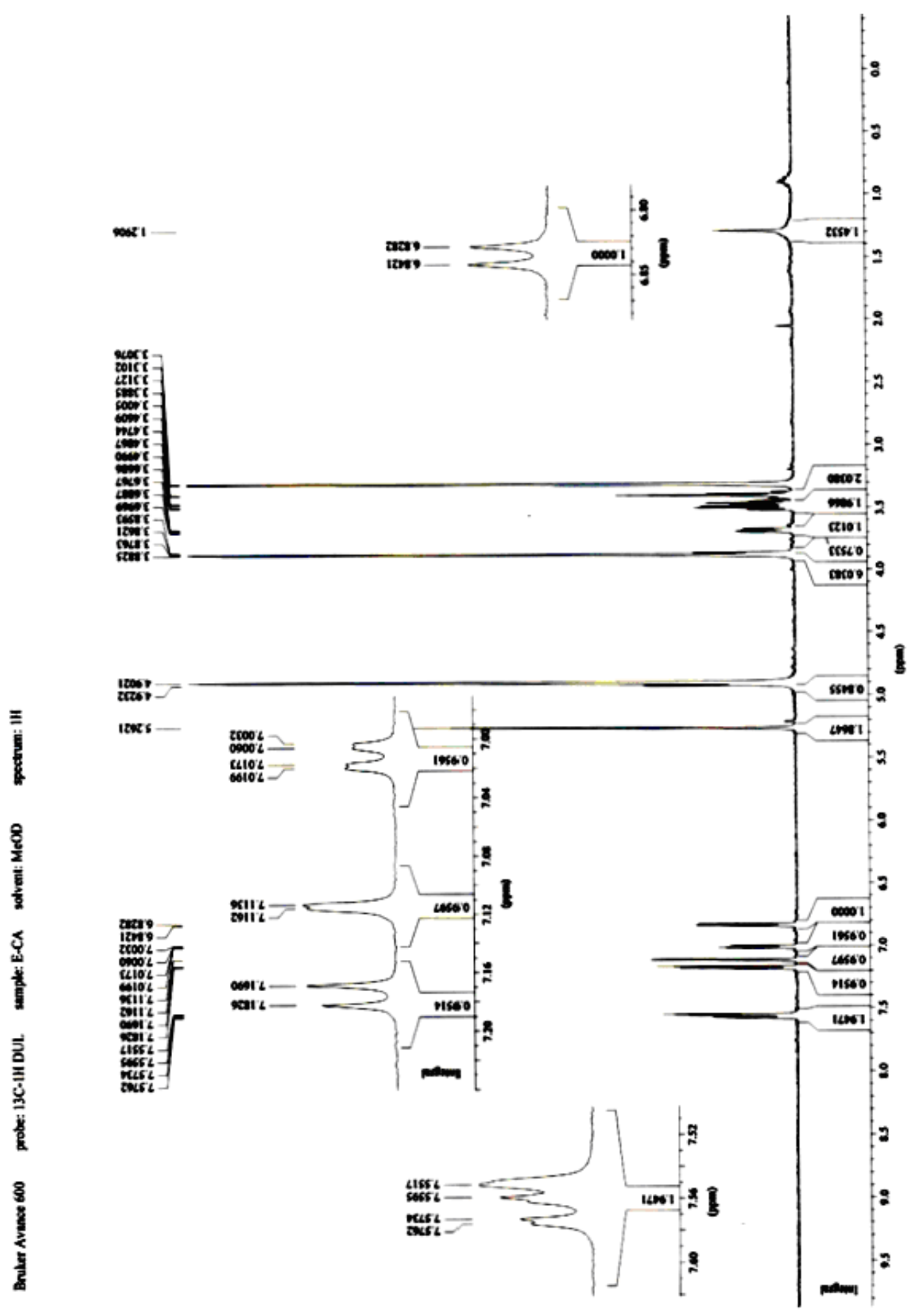


S12. ${ }^{13} \mathrm{C}$ NMR $\left(\mathrm{CD}_{3} \mathrm{OD}, 150 \mathrm{MHz}\right)$ Spectrum of Litseaefoloside B (2)

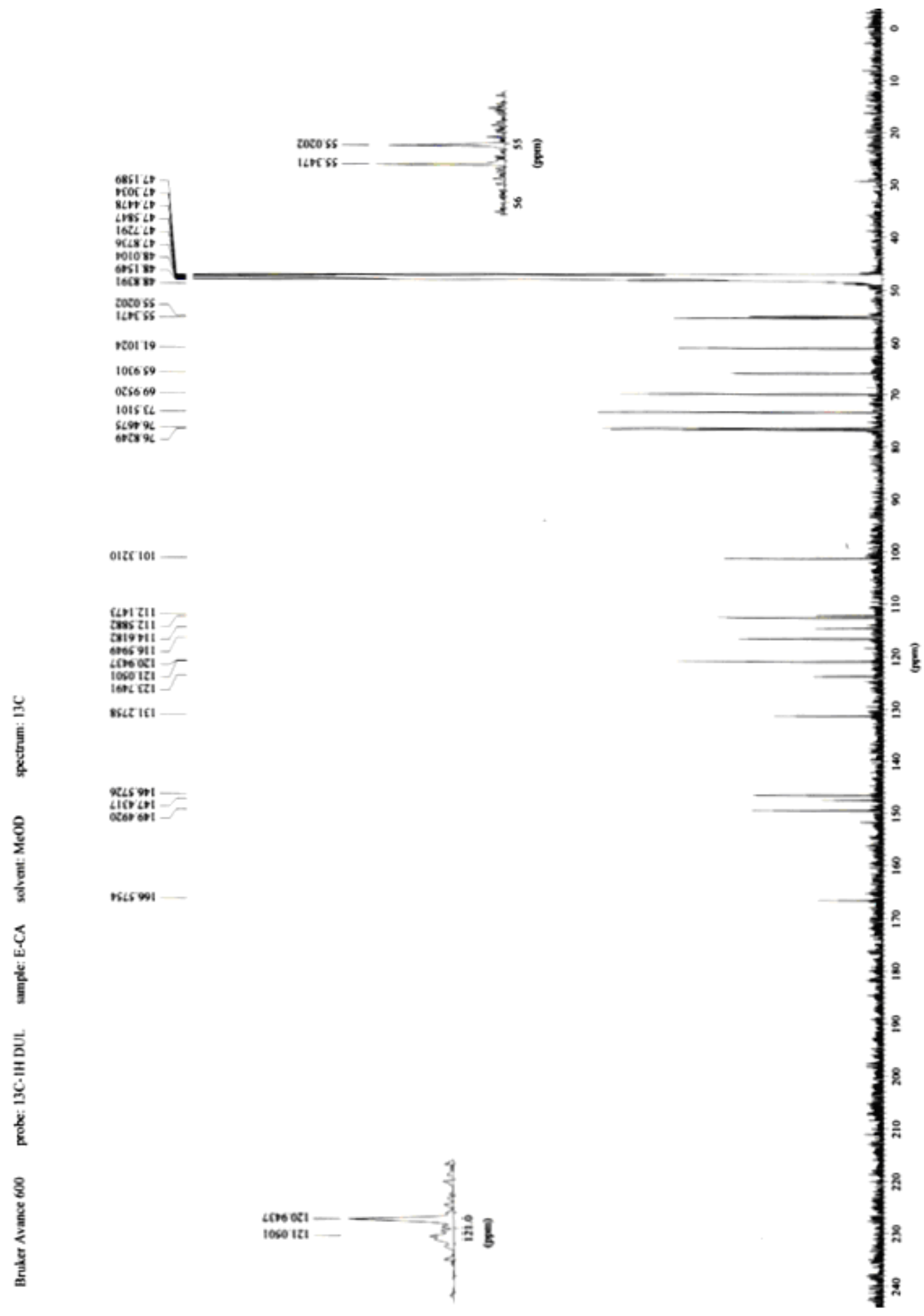


S13. HSQC Spectrum of Litseaefoloside B (2)

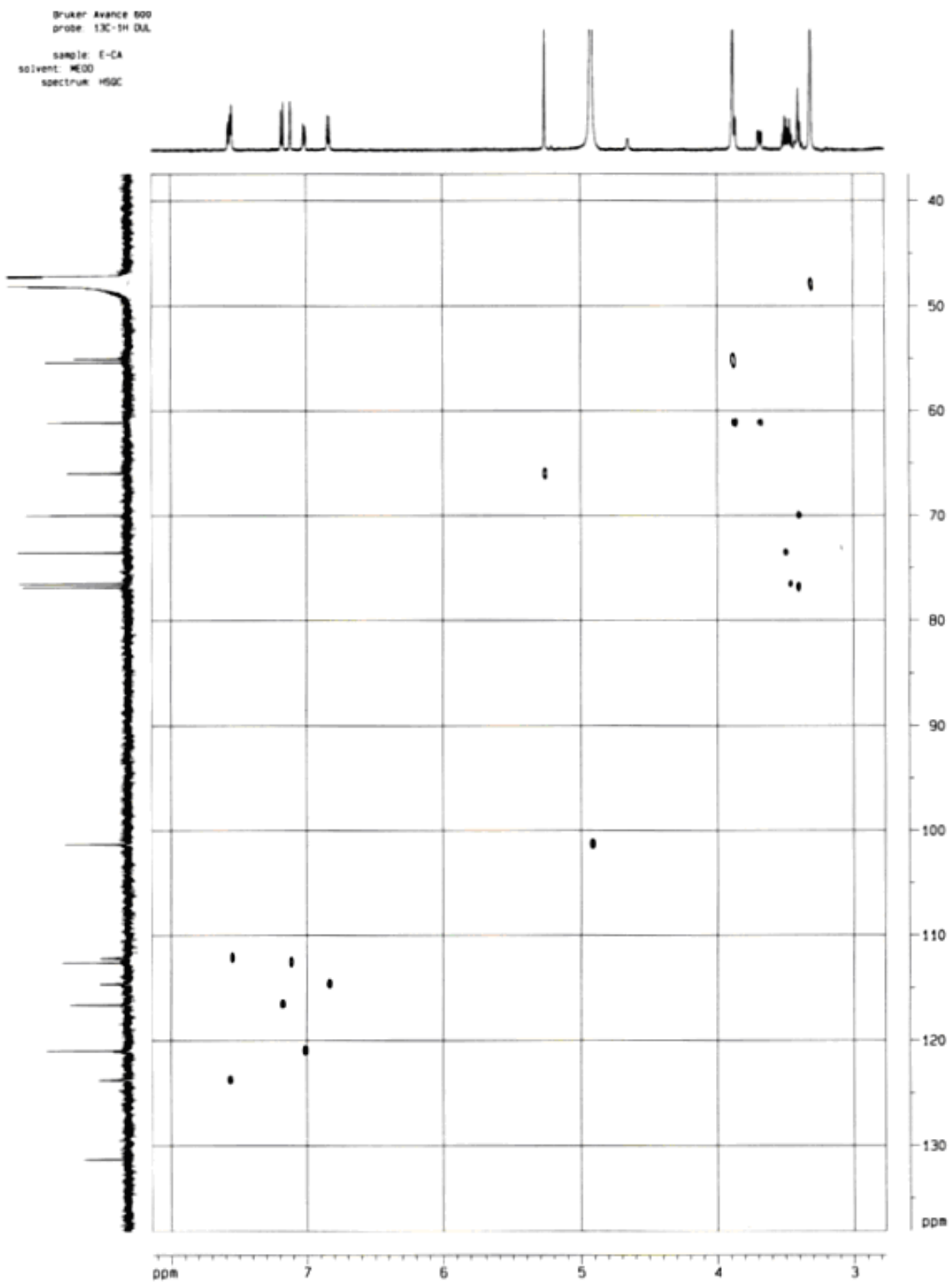


S14. HMBC Spectrum of Litseaefoloside B (2)

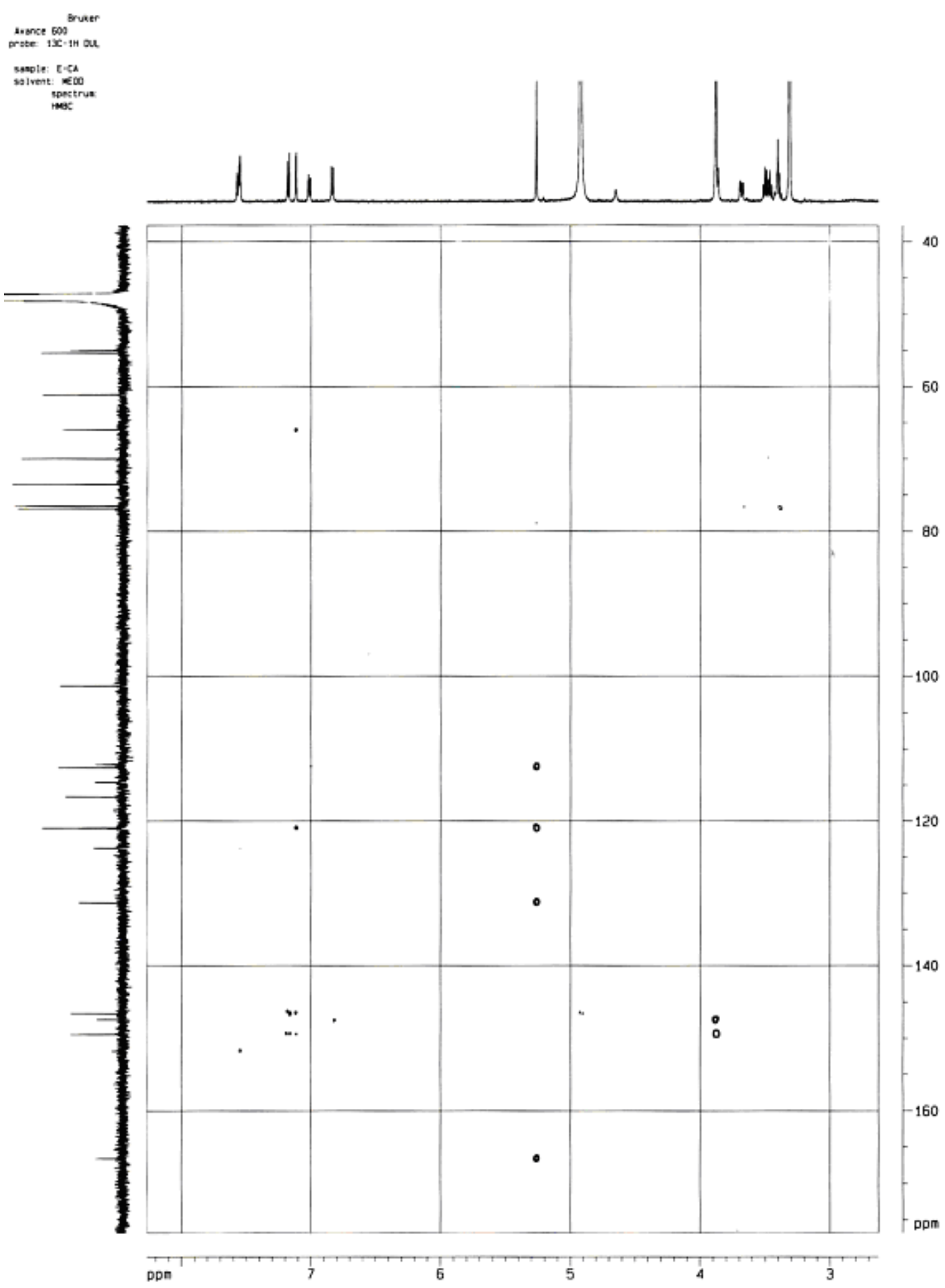


S15. NOESY Spectrum of Litseaefoloside B (2)
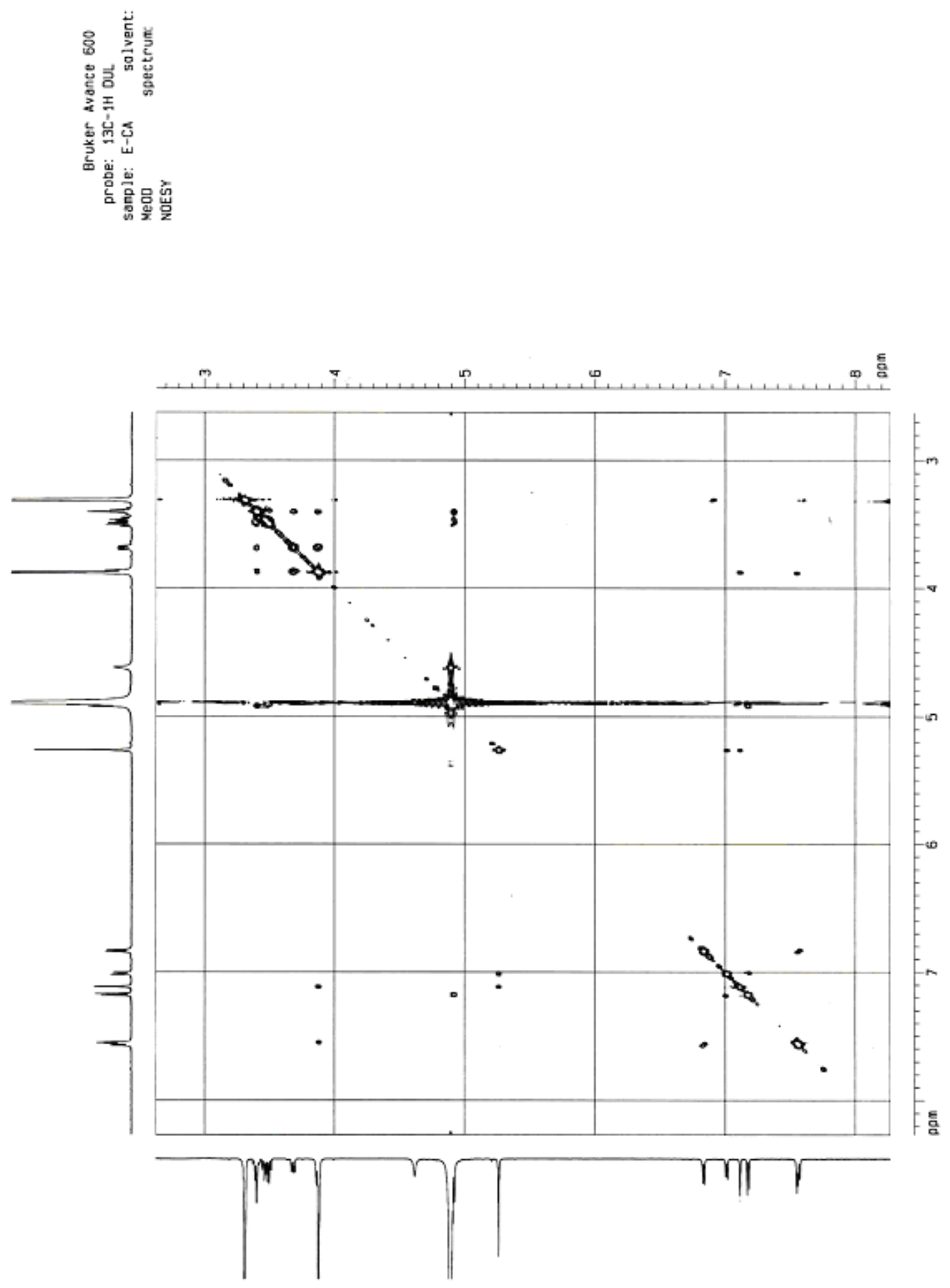
S16. HRESIMS of Litseaefoloside C (3)

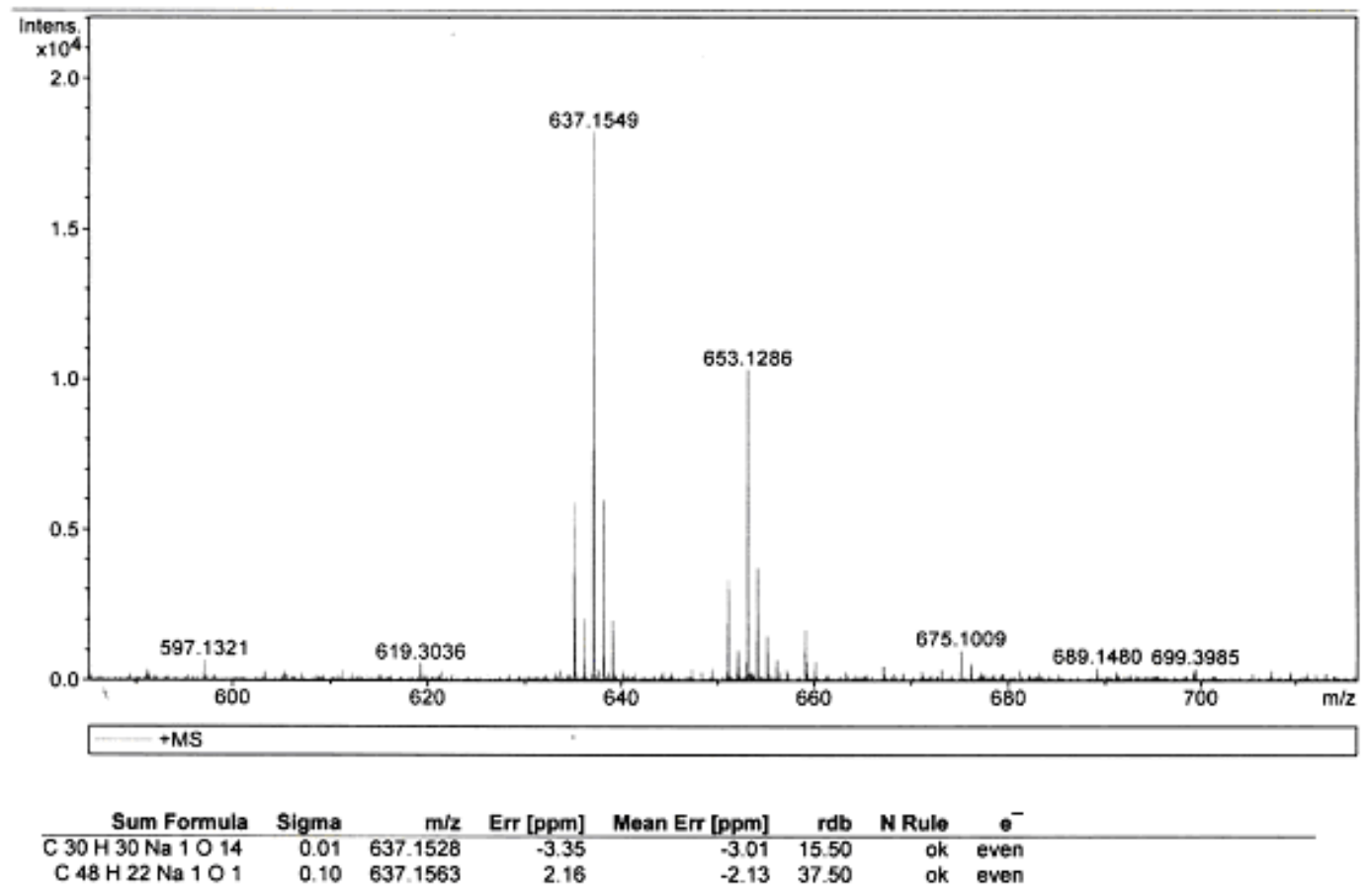

S17. ESIMS of Litseaefoloside C (3)

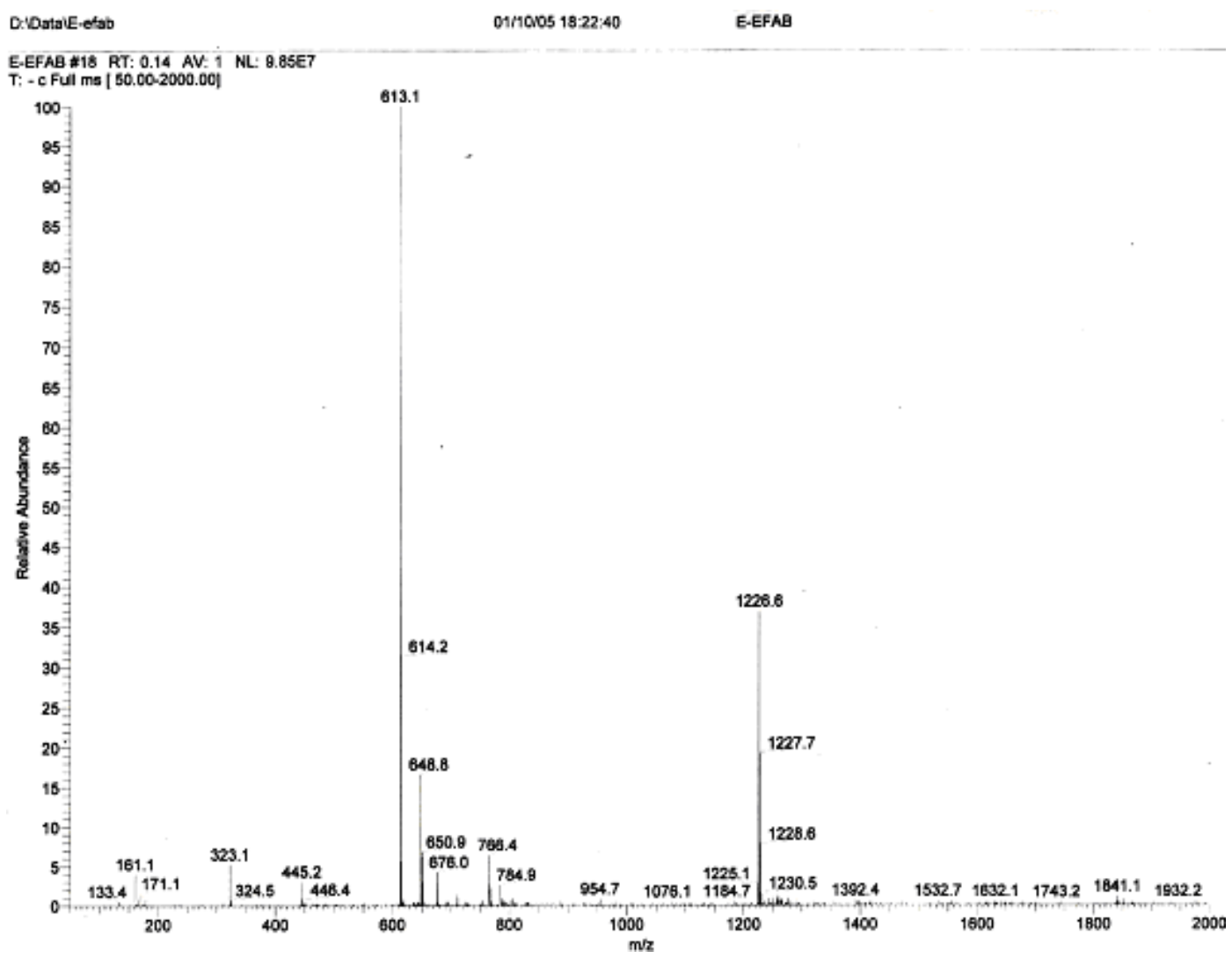


S18. ${ }^{1} \mathrm{H}$ NMR $\left(\mathrm{CD}_{3} \mathrm{OD}, 600 \mathrm{MHz}\right)$ Spectrum of Litseaefoloside C (3)

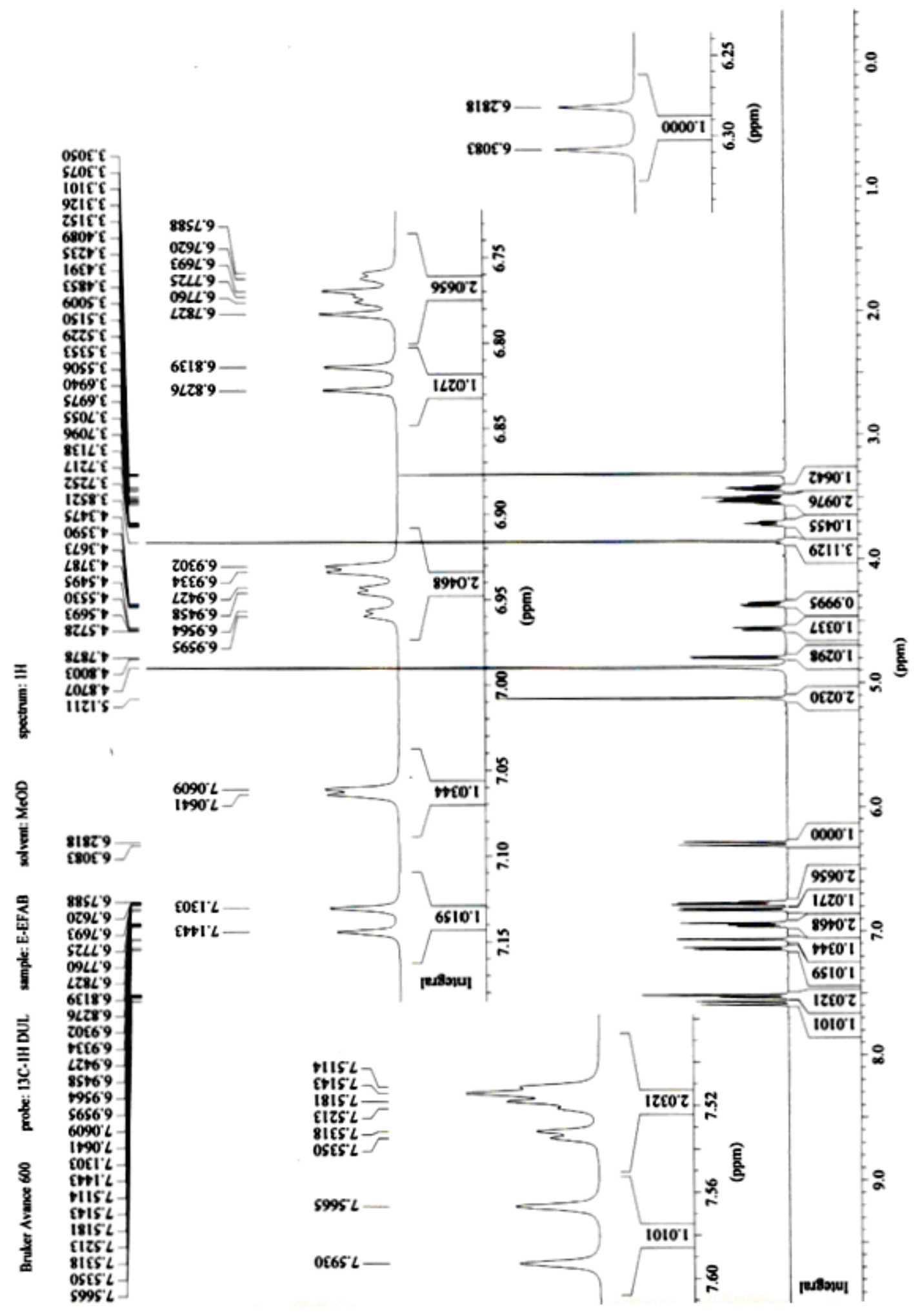


S19. ${ }^{13} \mathrm{C}$ NMR $\left(\mathrm{CD}_{3} \mathrm{OD}, 150 \mathrm{MHz}\right)$ Spectrum of Litseaefoloside C (3)

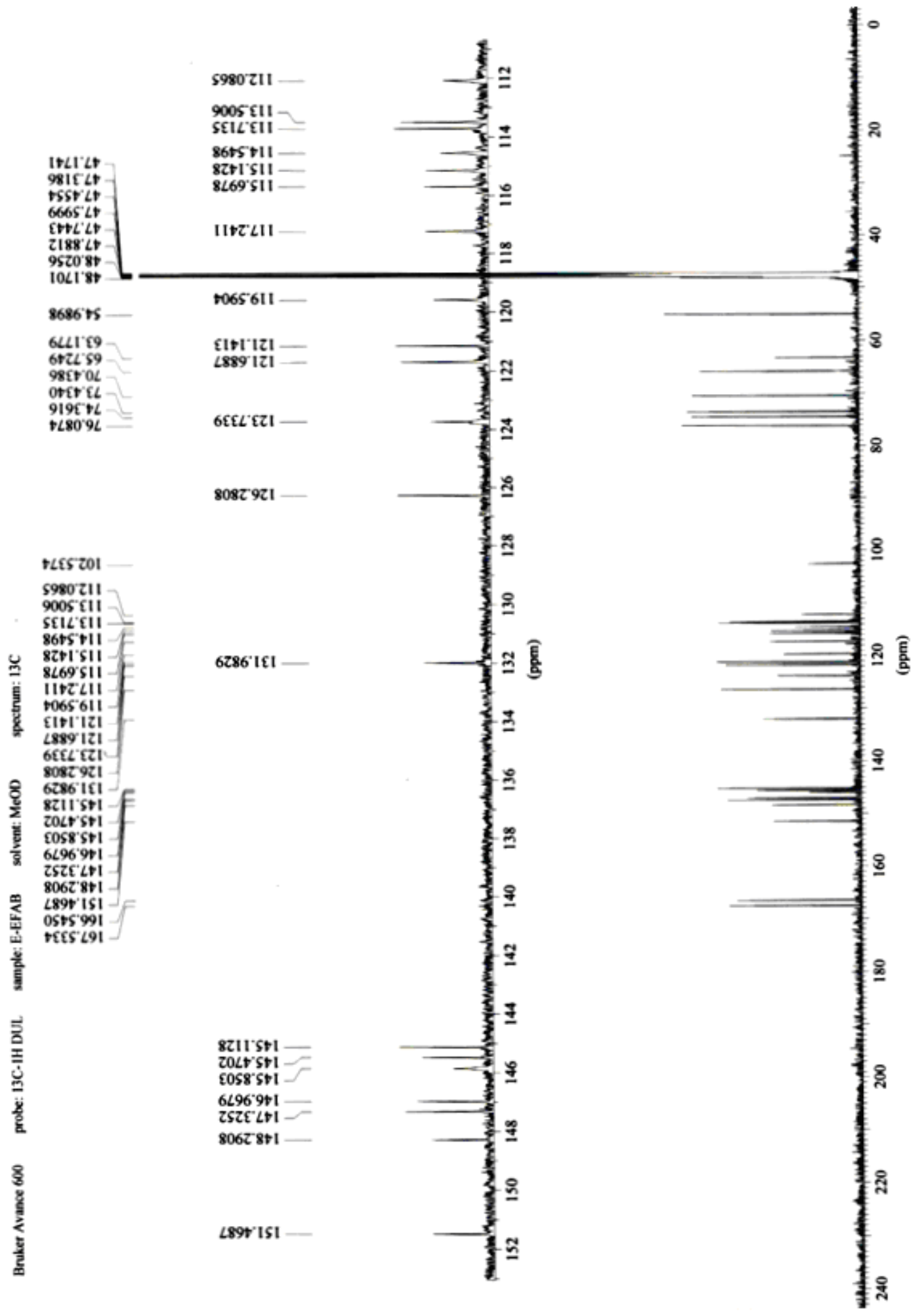


S20. HSQC Spectrum of Litseaefoloside C (3)

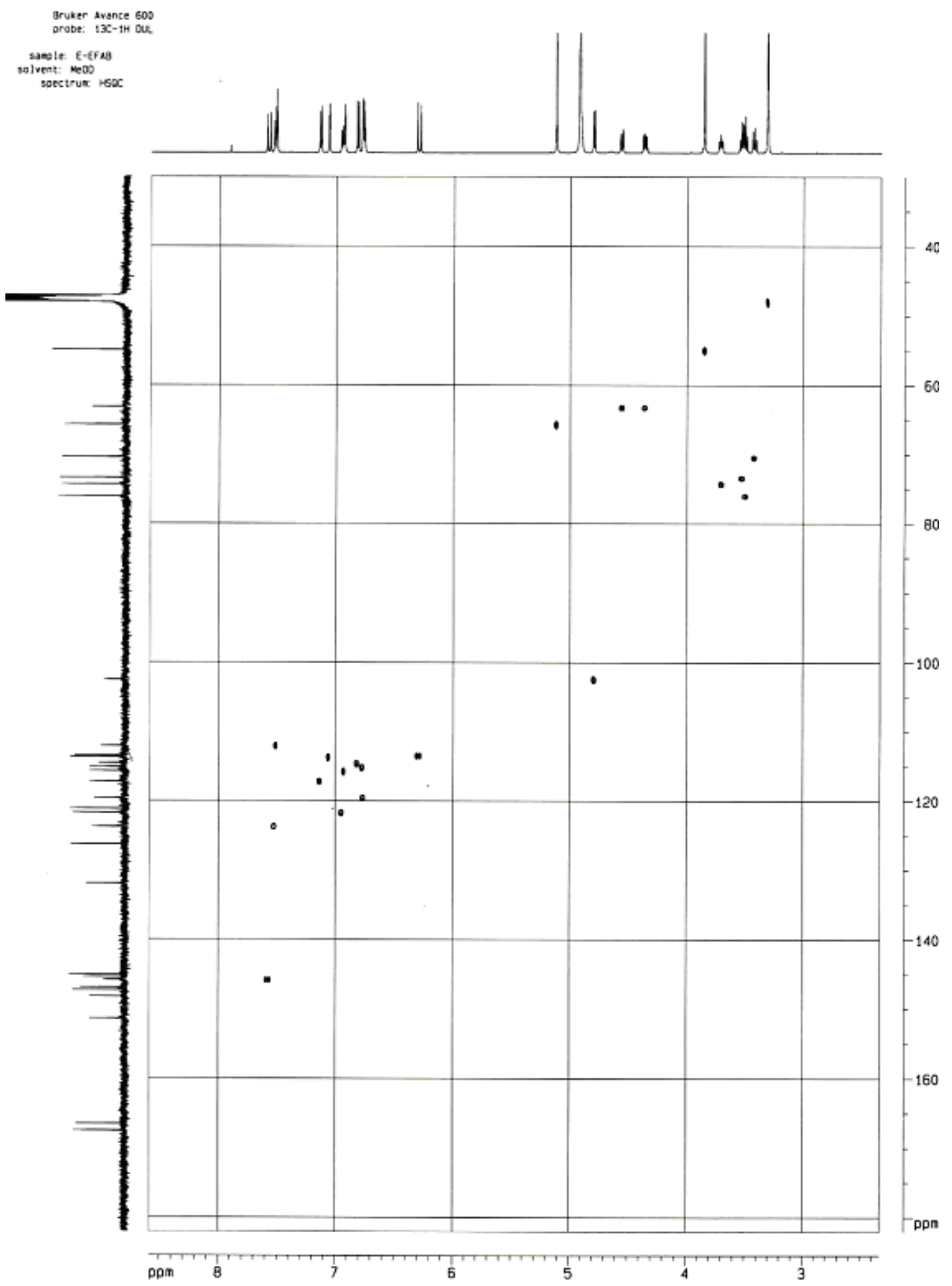


S21. HMBC Spectrum of Litseaefoloside C (3)

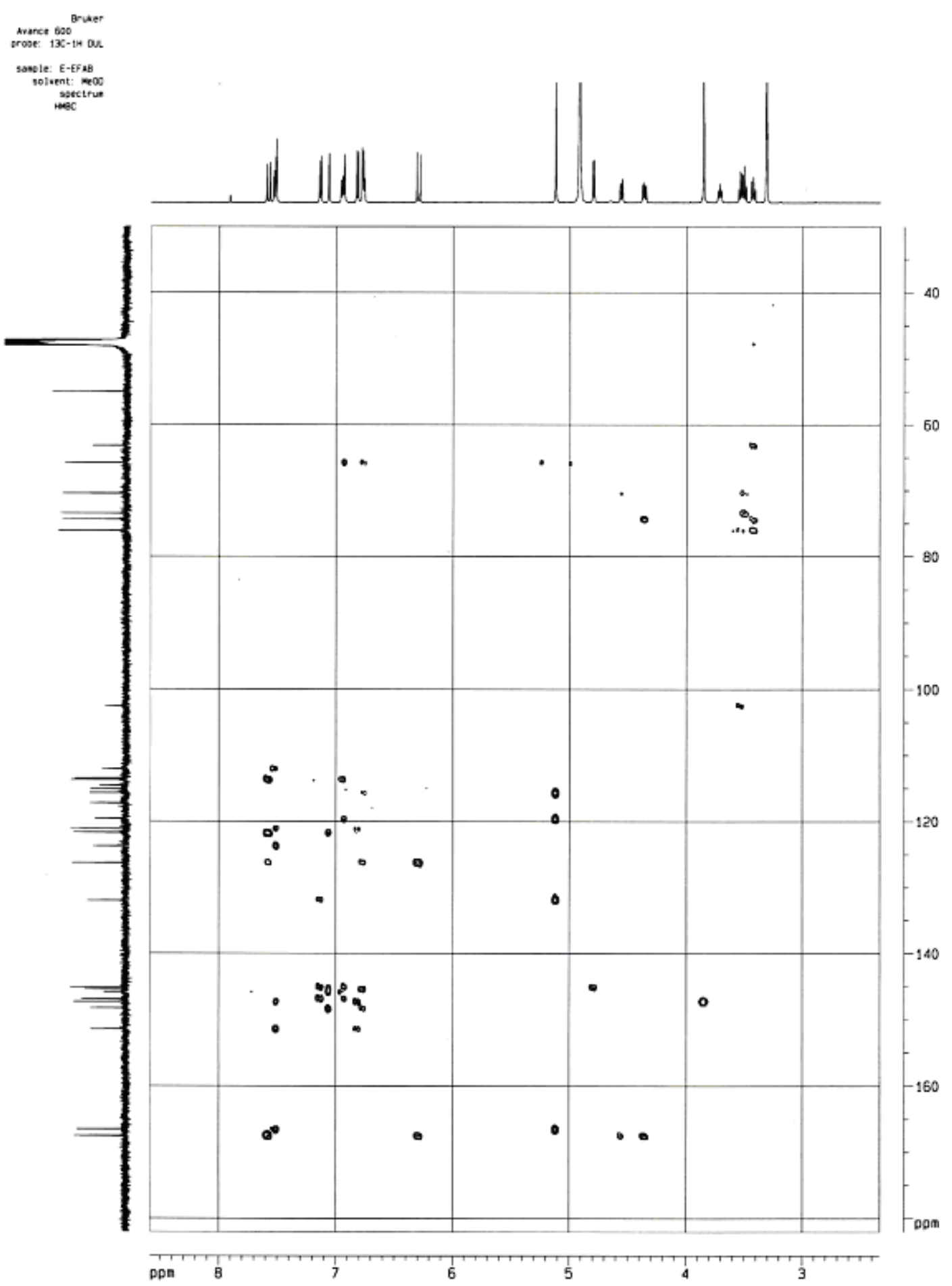


S22. NOESY Spectrum of Litseaefoloside C (3)
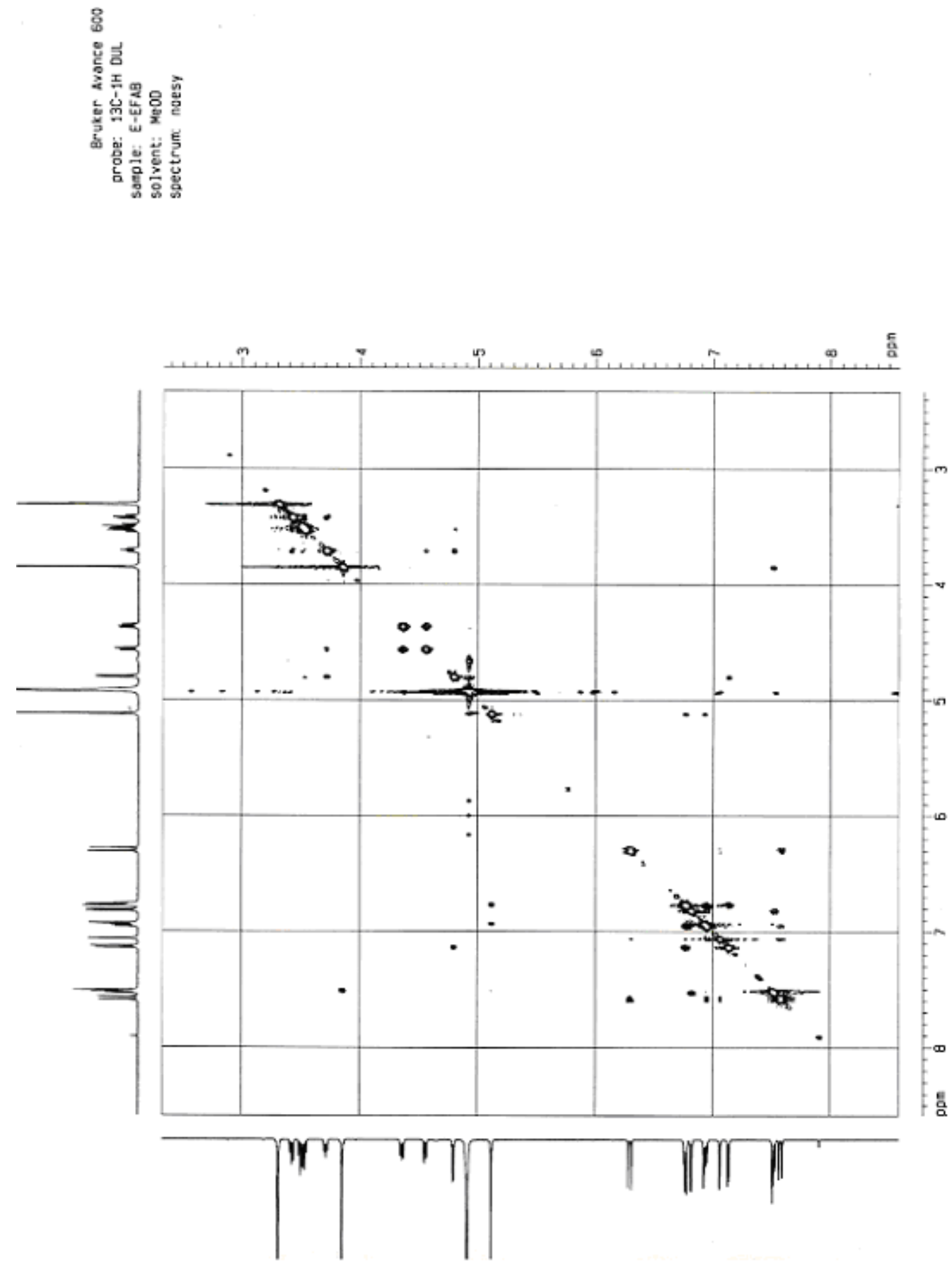
S23. HRESIMS of Litseaefoloside D (4)

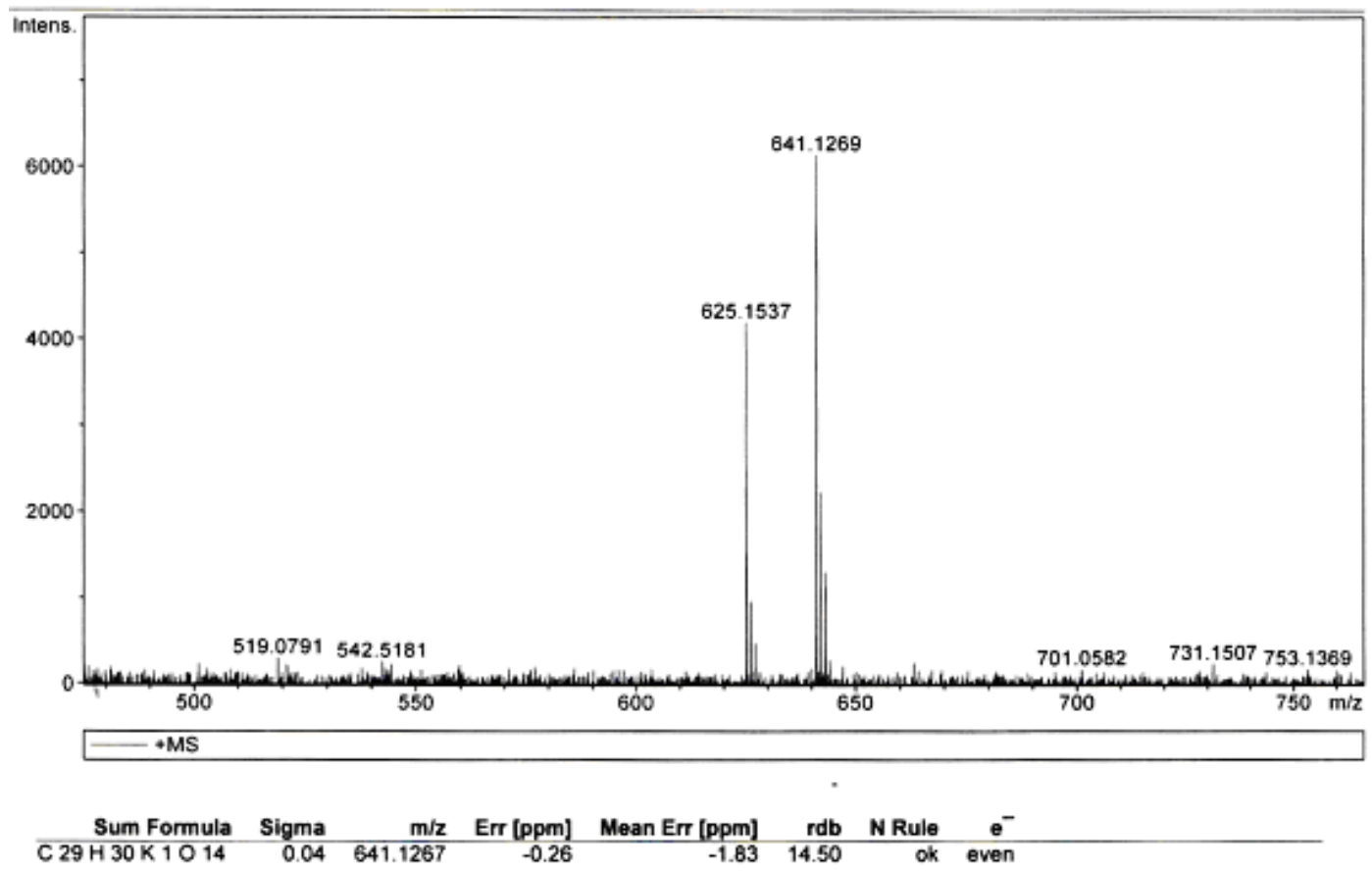

S24. ESIMS of Litseaefoloside D (4)
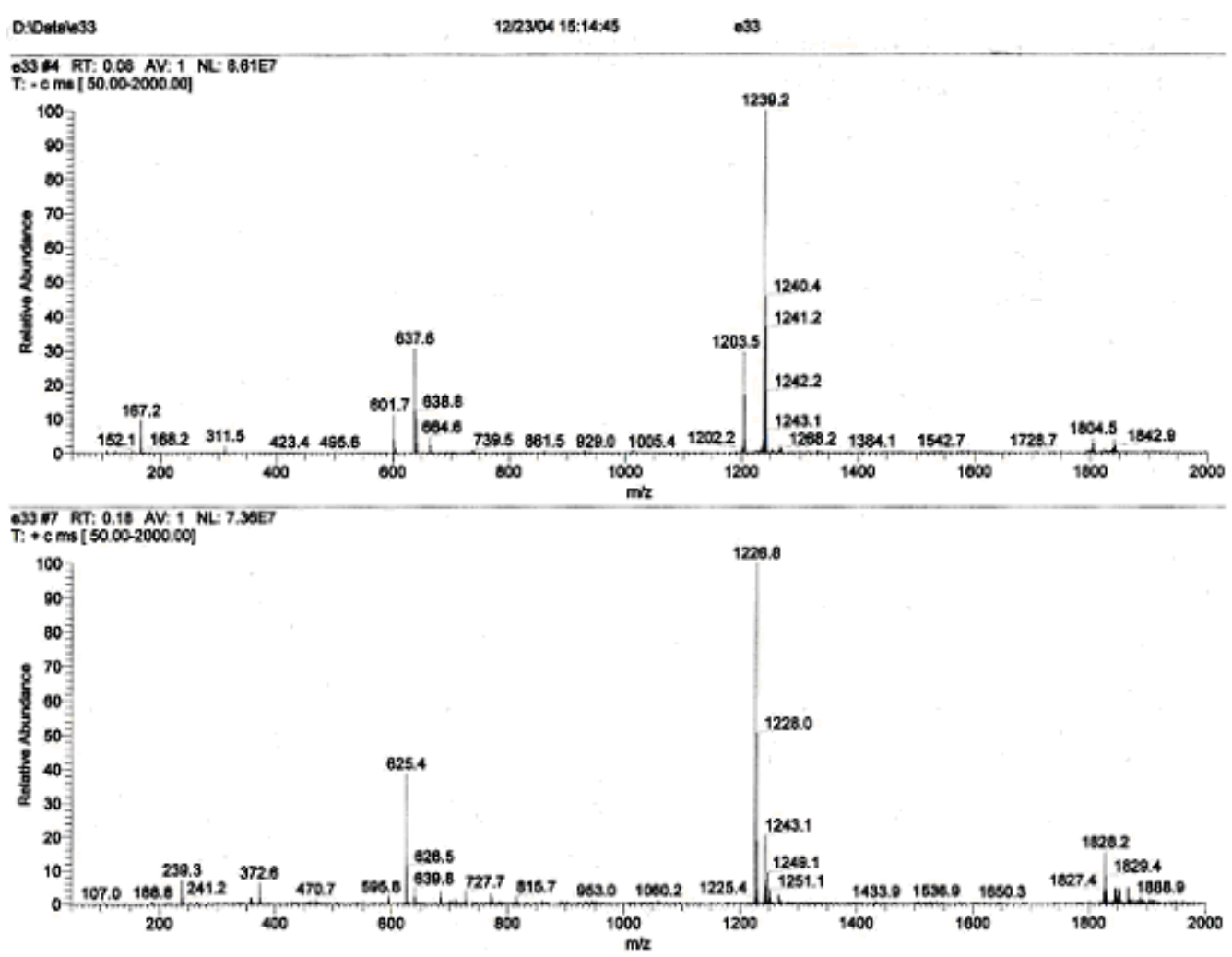
S25. ${ }^{1} \mathrm{H}$ NMR $\left(\mathrm{CD}_{3} \mathrm{OD}, 600 \mathrm{MHz}\right)$ Spectrum of Litseaefoloside D (4)

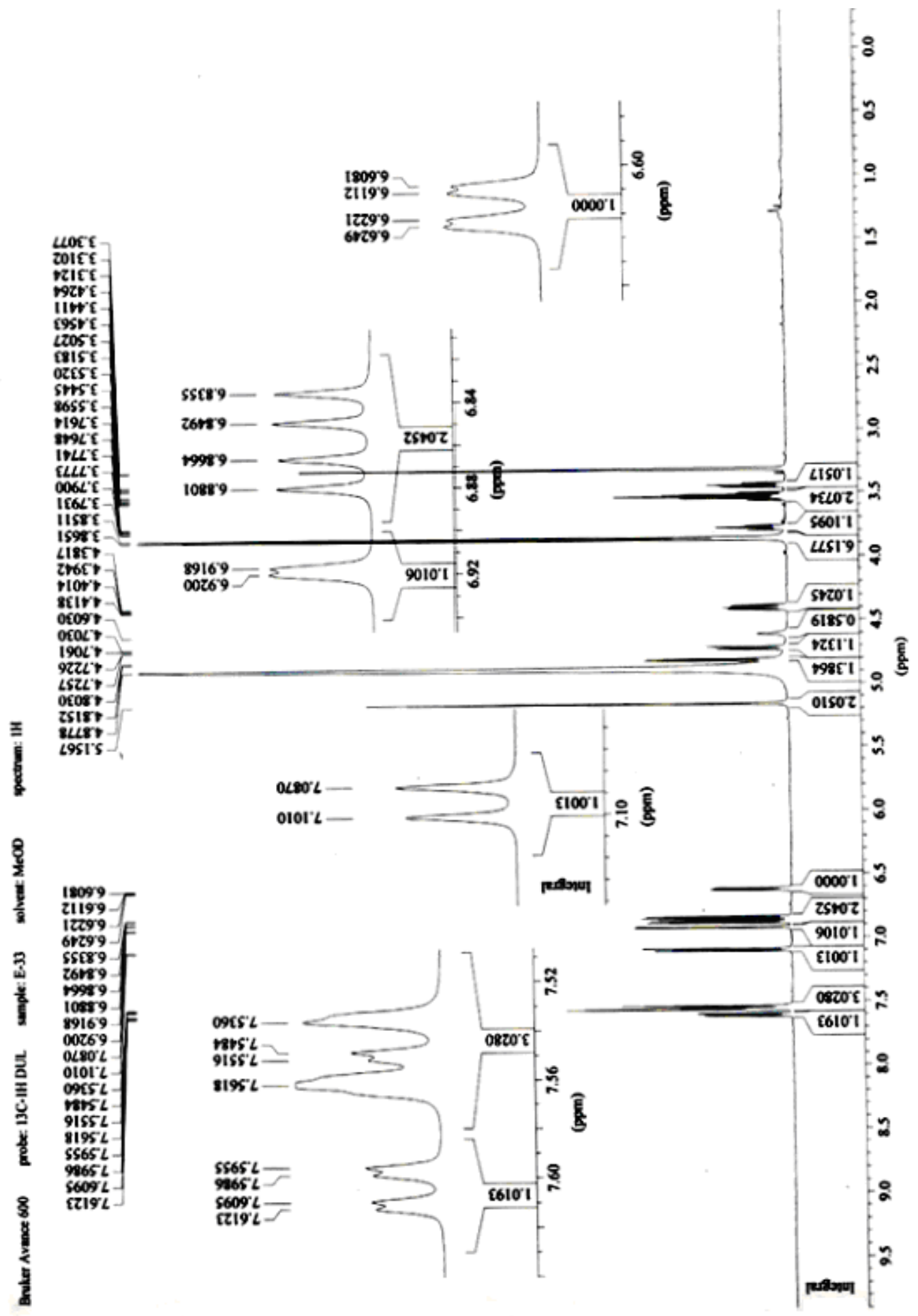


S26. ${ }^{13} \mathrm{C}$ NMR $\left(\mathrm{CD}_{3} \mathrm{OD}, 150 \mathrm{MHz}\right)$ Spectrum of Litseaefoloside D (4)

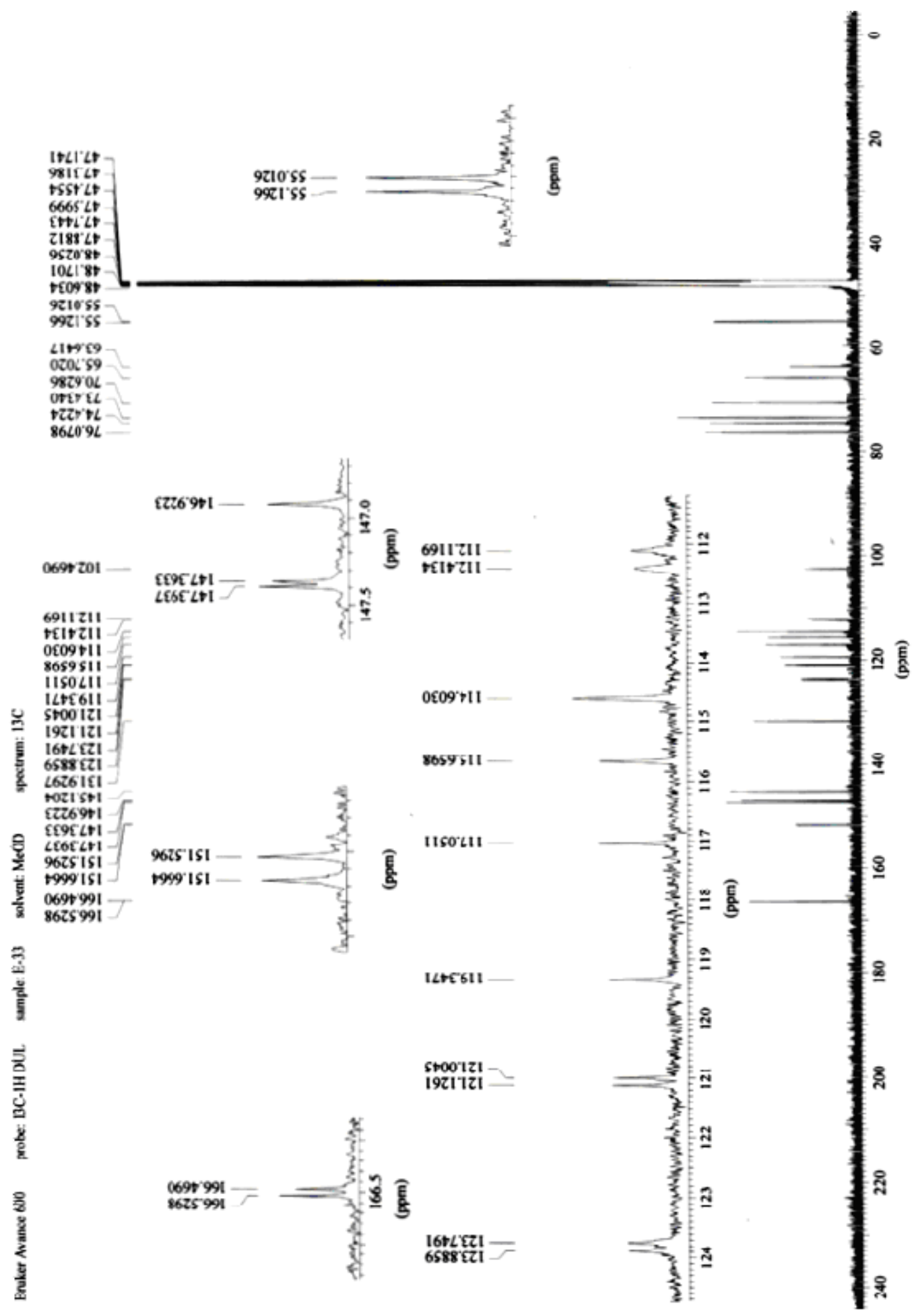


S27. HSQC Spectrum of Litseaefoloside D (4)

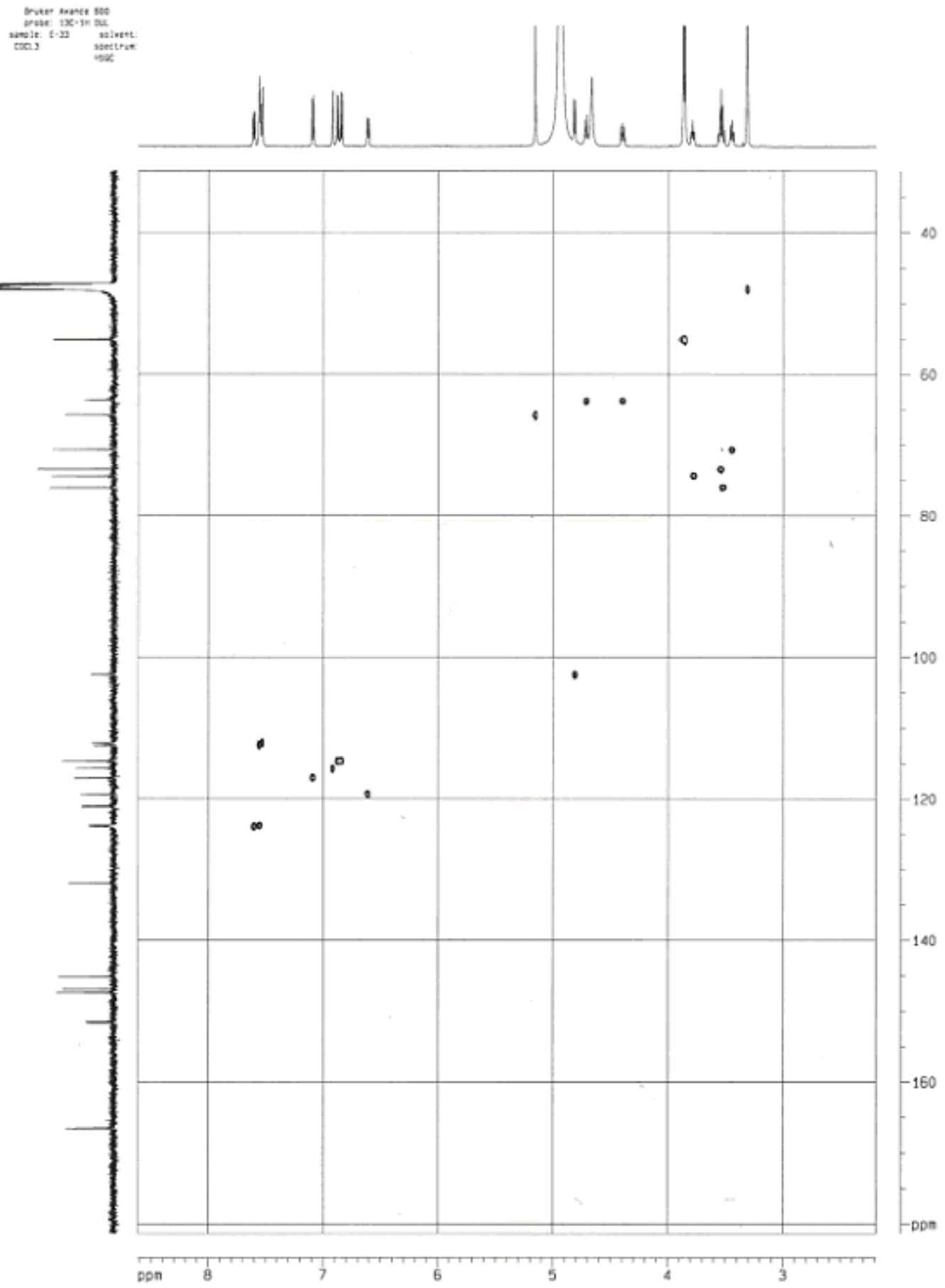


S28. HMBC Spectrum of Litseaefoloside D (4)

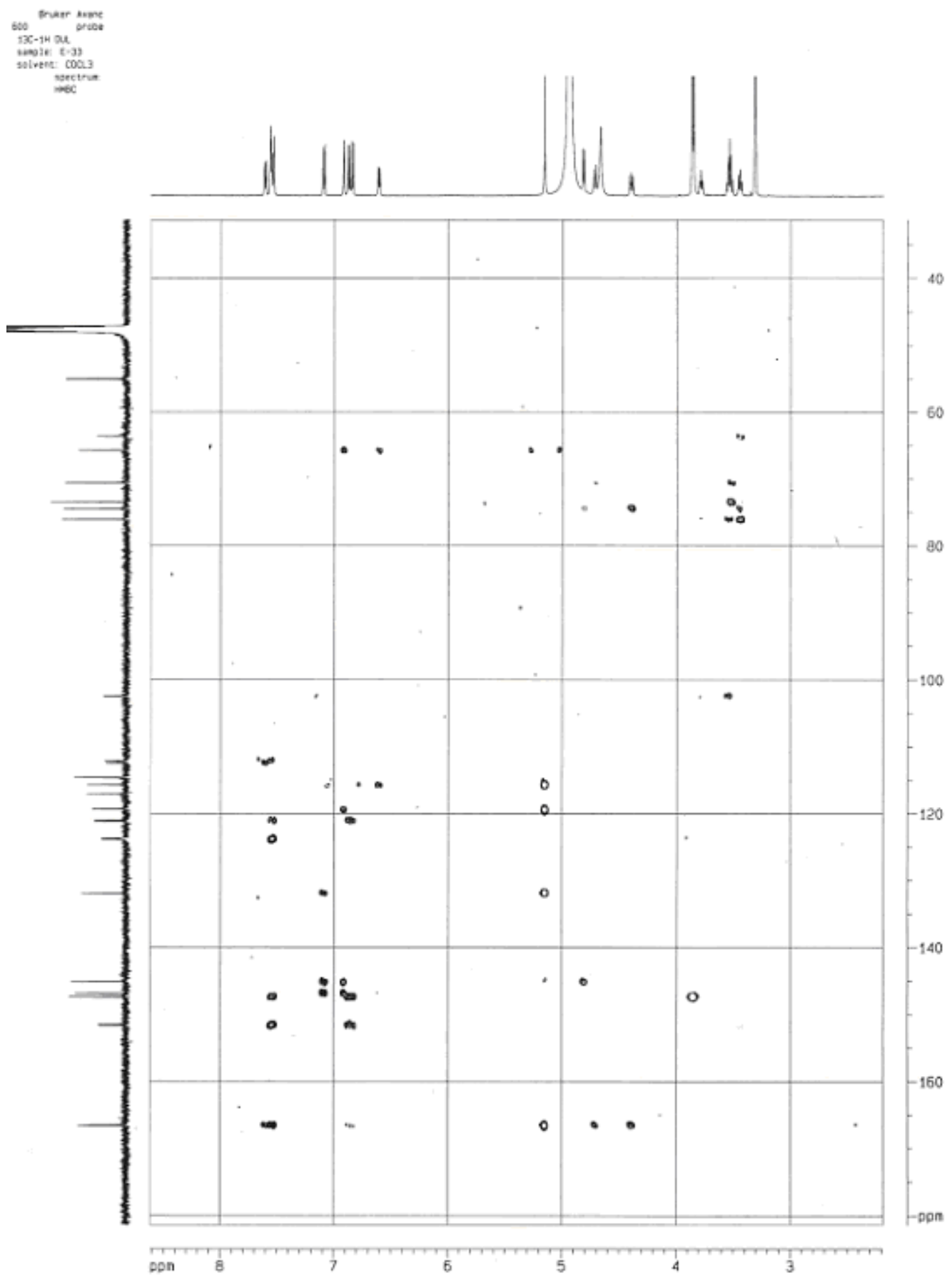


S29. NOESY Spectrum of Litseaefoloside D (4)
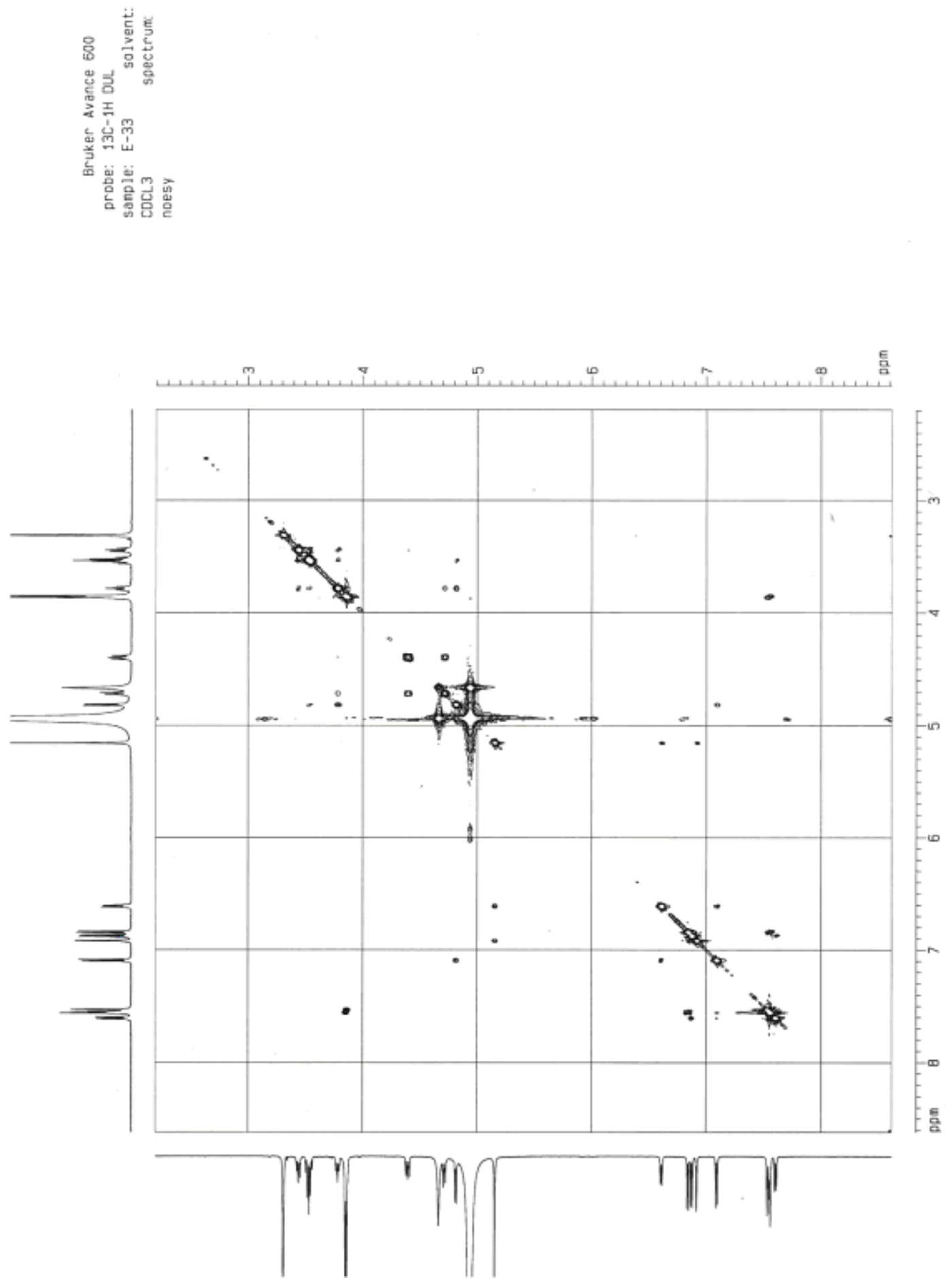
S30. HRESIMS of Spathodic acid 28-O- $\beta$-D-glucopyranoside (5)

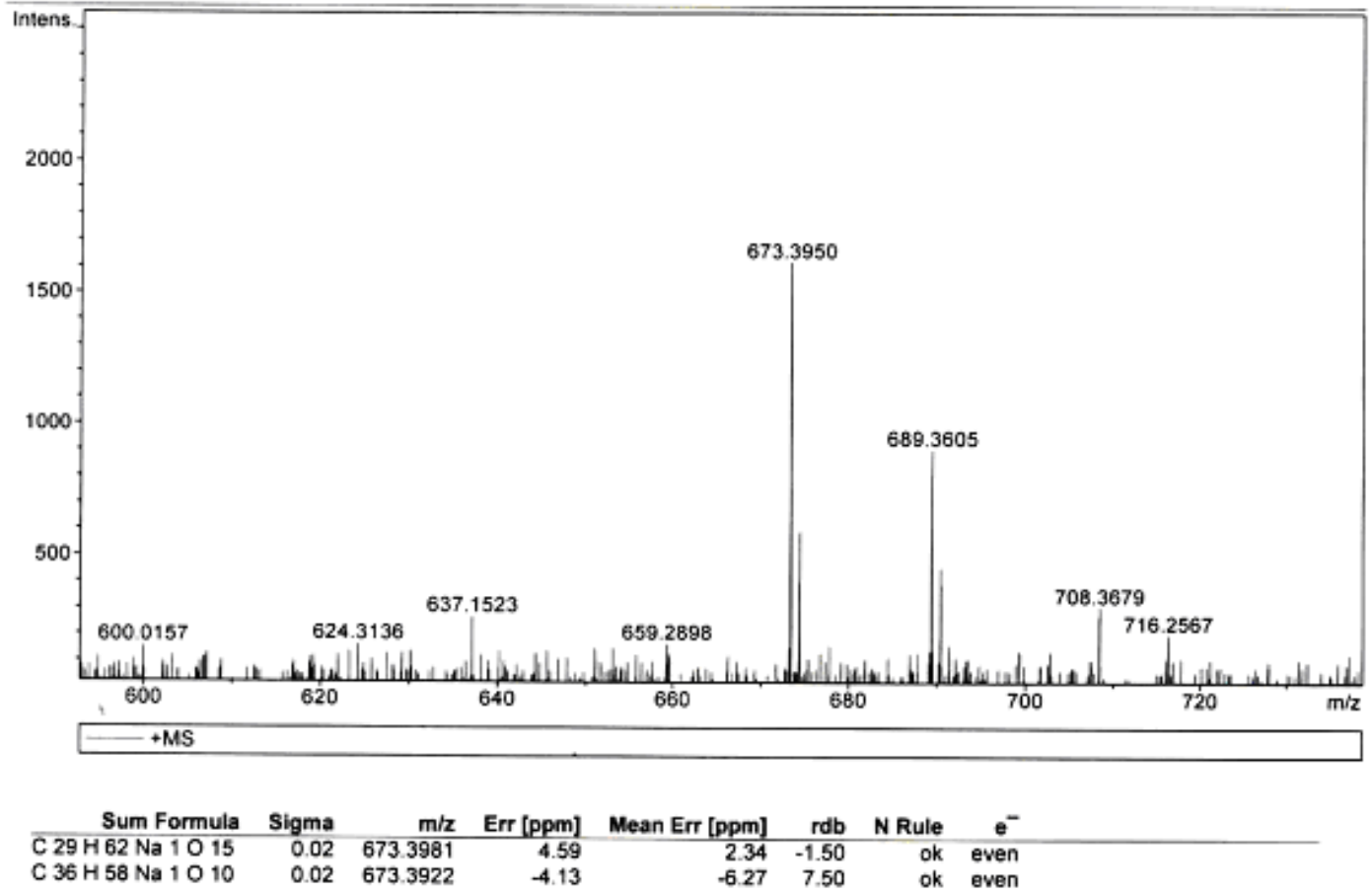

S31. ESIMS of Spathodic acid 28-O- $\beta$-D-glucopyranoside (5)

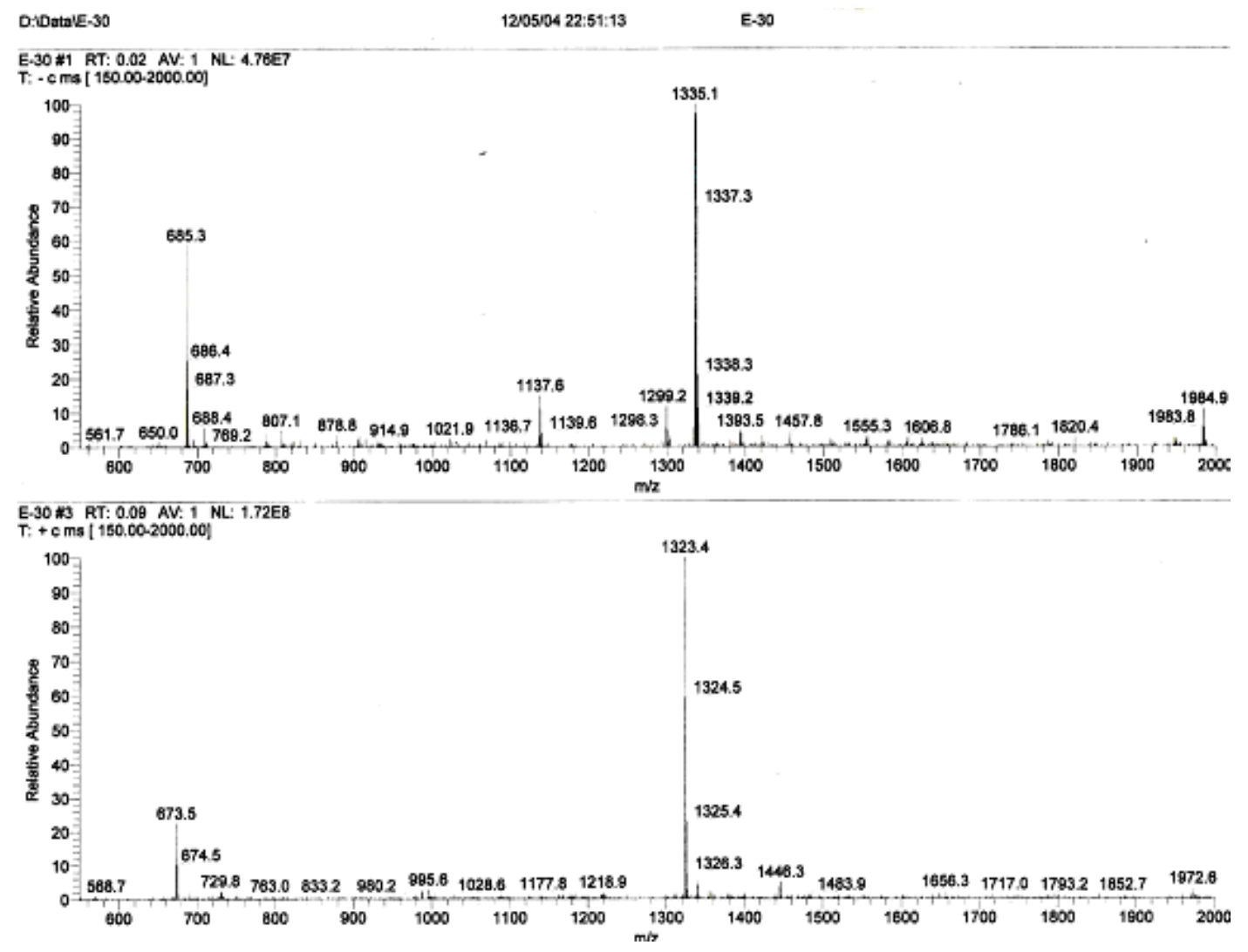


S32. ${ }^{1} \mathrm{H}$ NMR $\left(\mathrm{C}_{5} \mathrm{D}_{5} \mathrm{~N}, 600 \mathrm{MHz}\right)$ Spectrum of Spathodic acid 28-O- $\beta$-D-glucopyranoside (5)

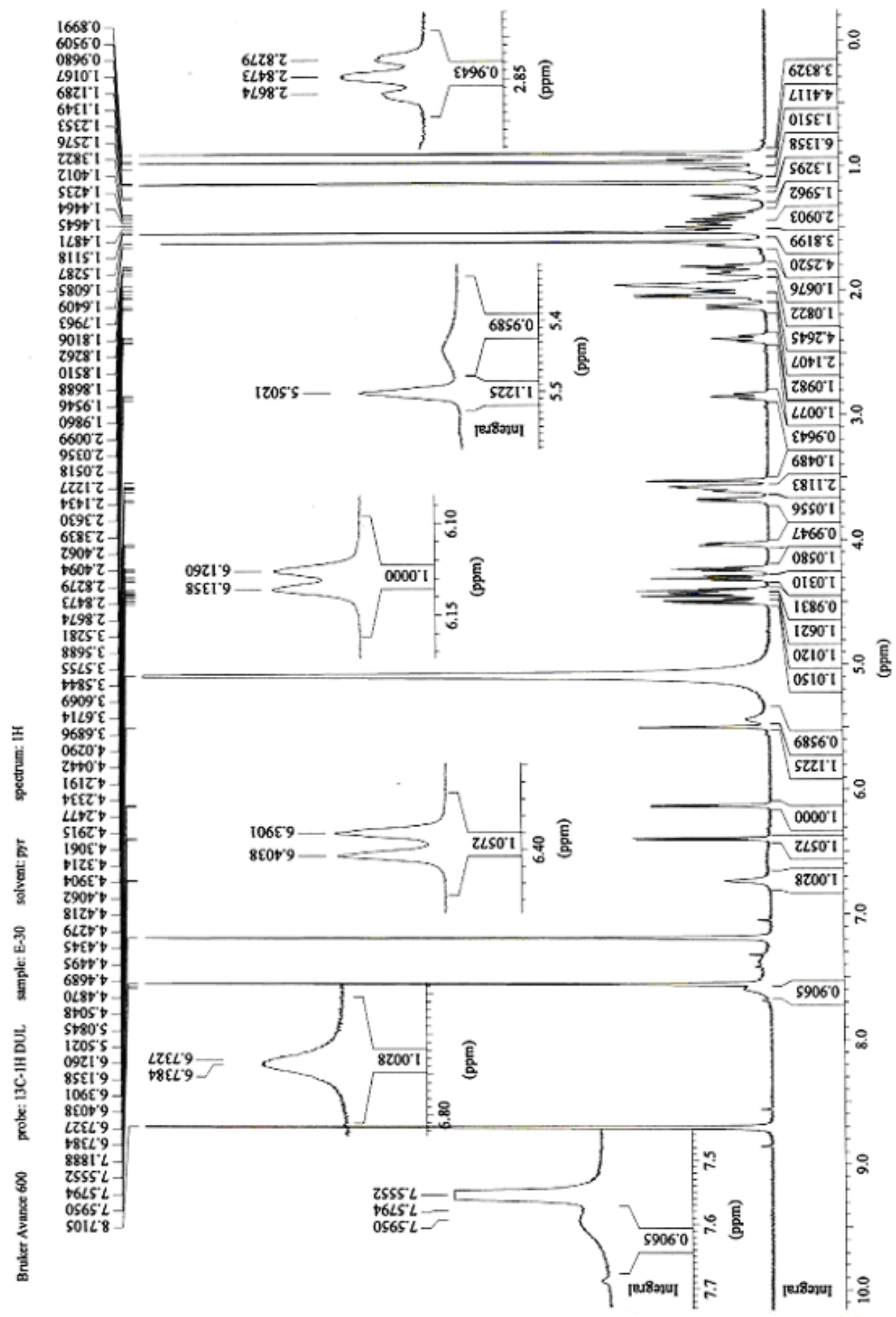


S33. ${ }^{13} \mathrm{C}$ NMR $\left(\mathrm{C}_{5} \mathrm{D}_{5} \mathrm{~N}, 150 \mathrm{MHz}\right)$ Spectrum of Spathodic acid 28-O- $\beta$-D-glucopyranoside (5)

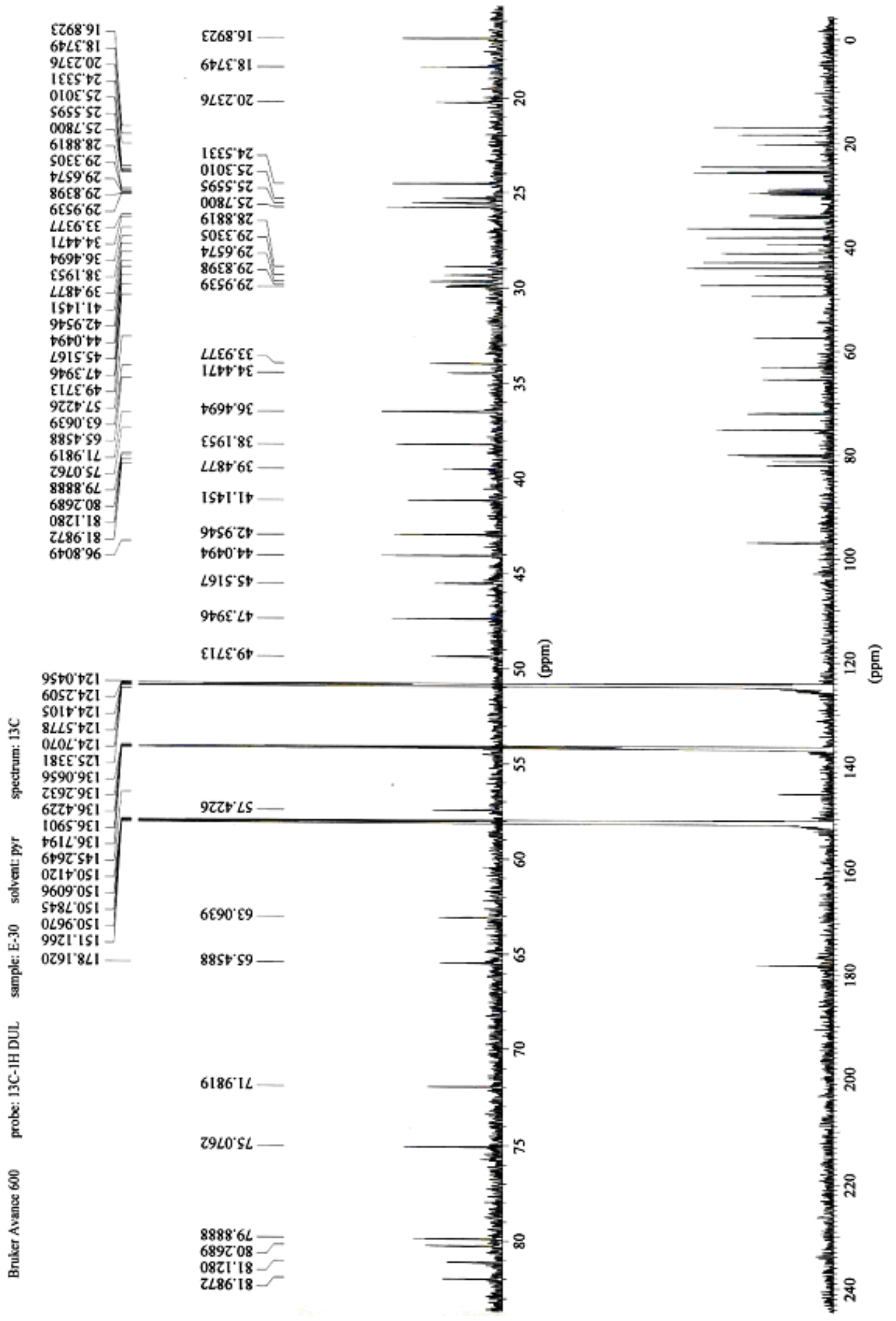


S34. HSQC Spectrum of Spathodic acid 28-O- $\beta$-D-glucopyranoside (5)

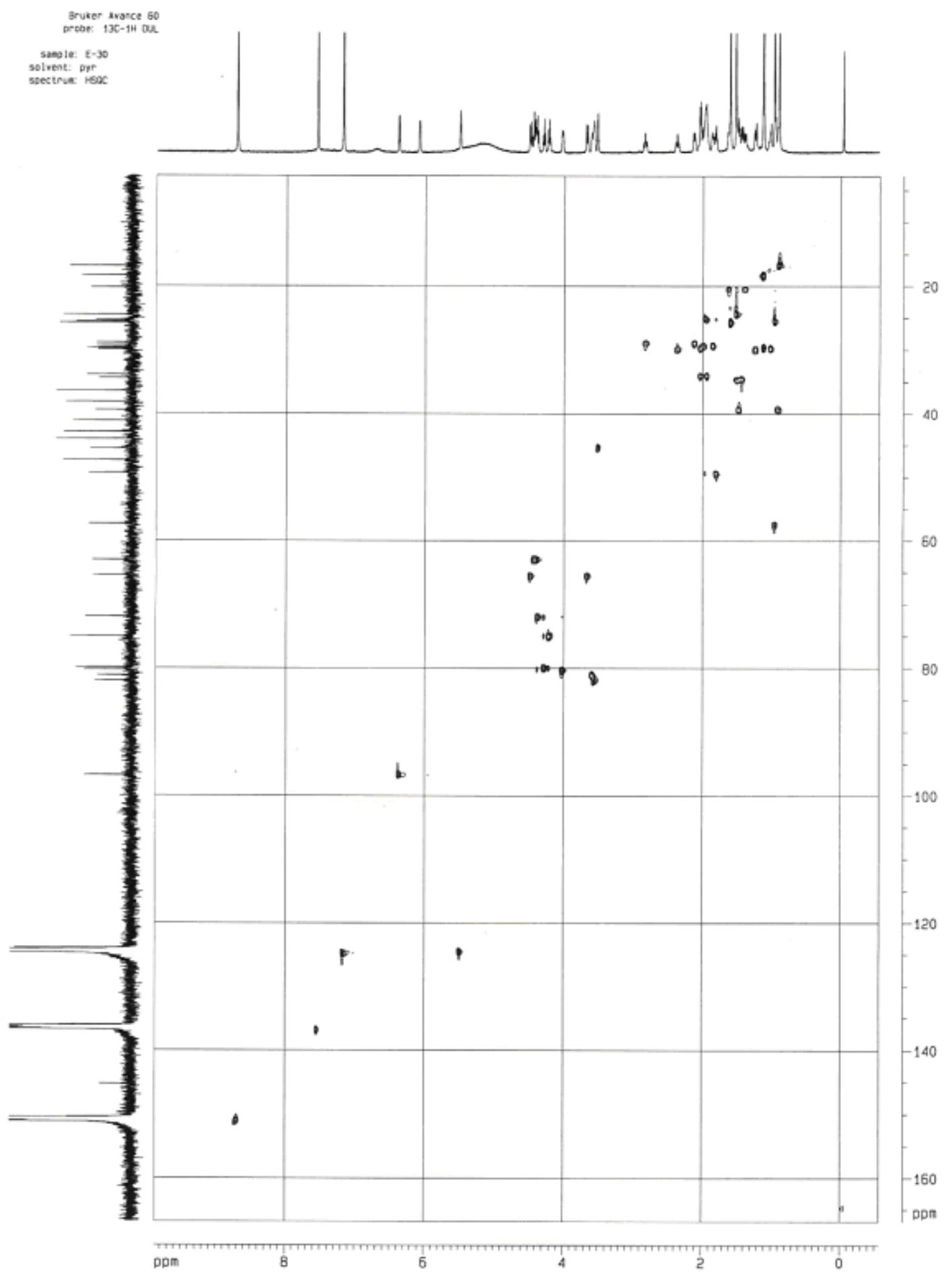


S35. HMBC Spectrum of Spathodic acid 28-O- $\beta$-D-glucopyranoside (5)

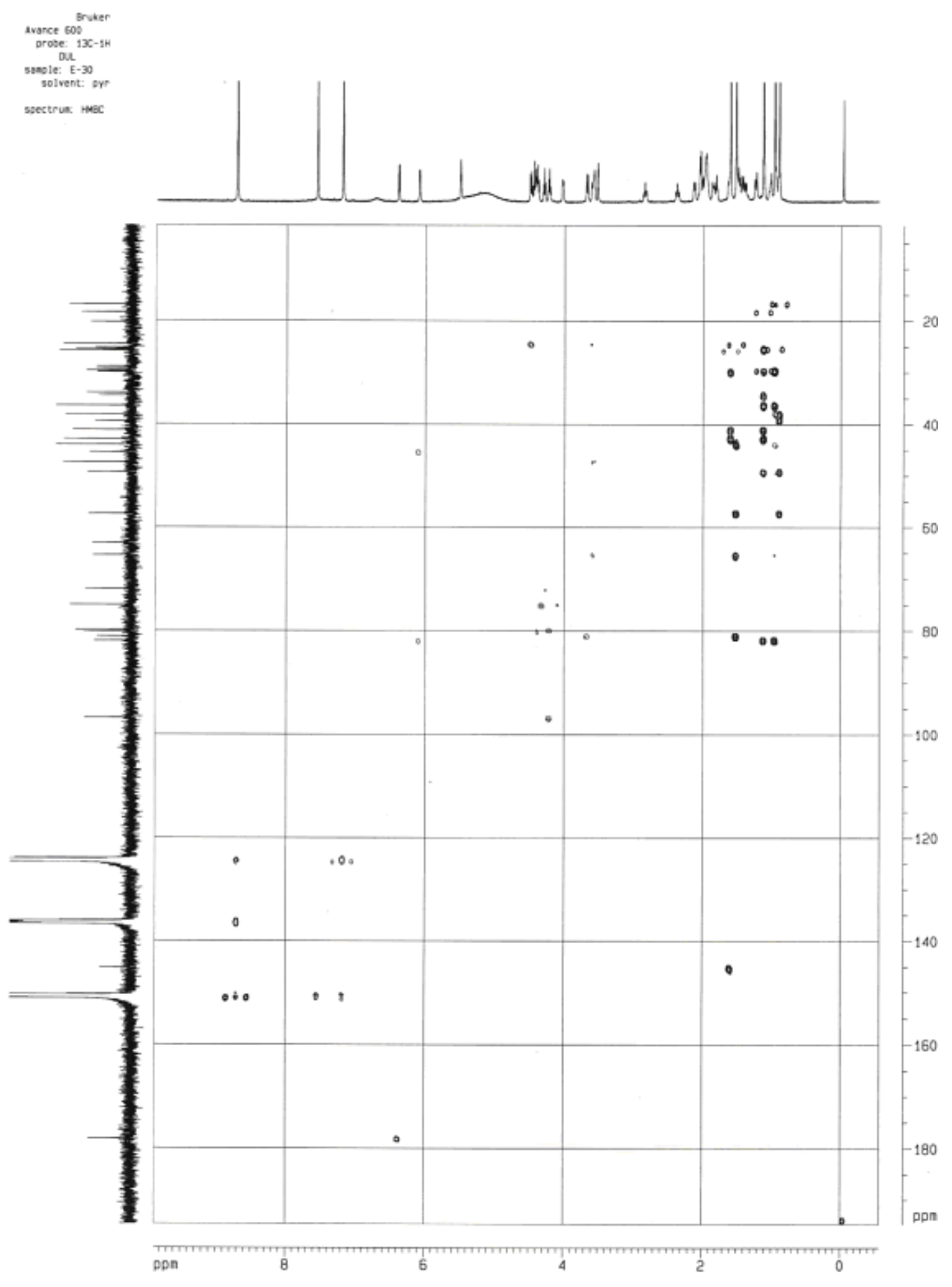


S36. NOESY Spectrum of Spathodic acid 28-O- $\beta$-D-glucopyranoside (5)
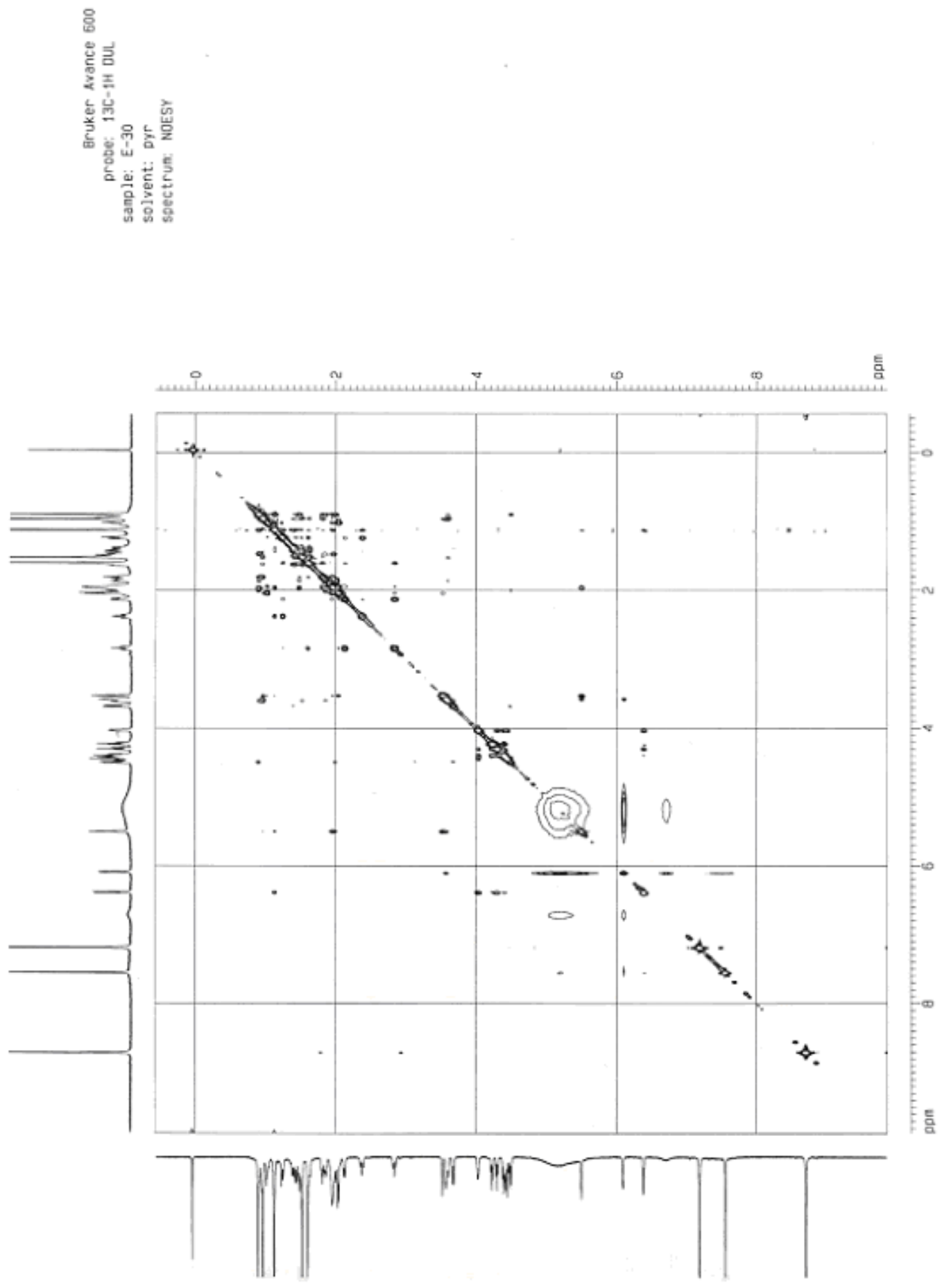
S37. HRESIMS of (20S)-Niga-ichigoside F1 (6)

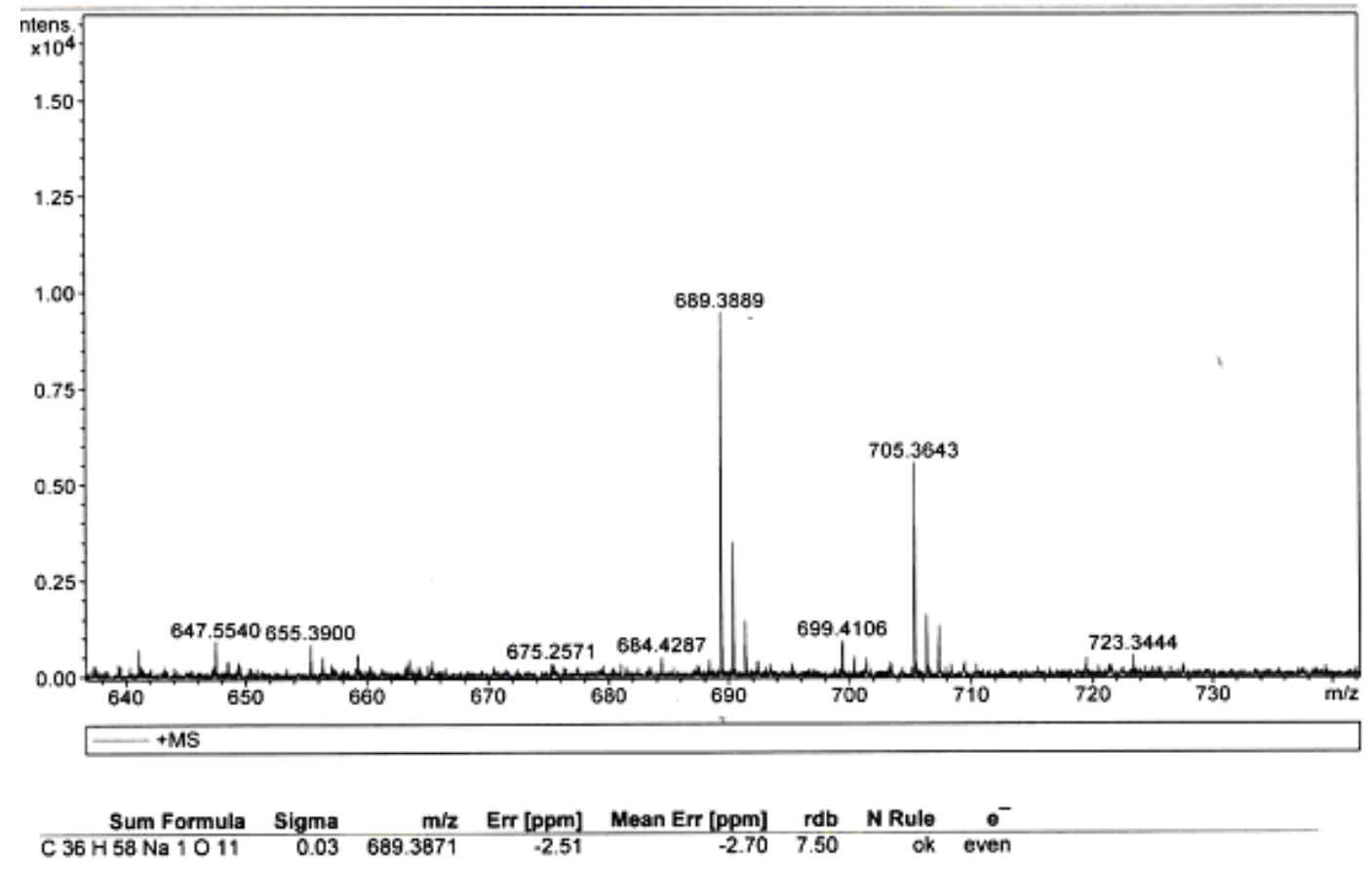

S38. ESIMS of (20S)-Niga-ichigoside F1 (6)

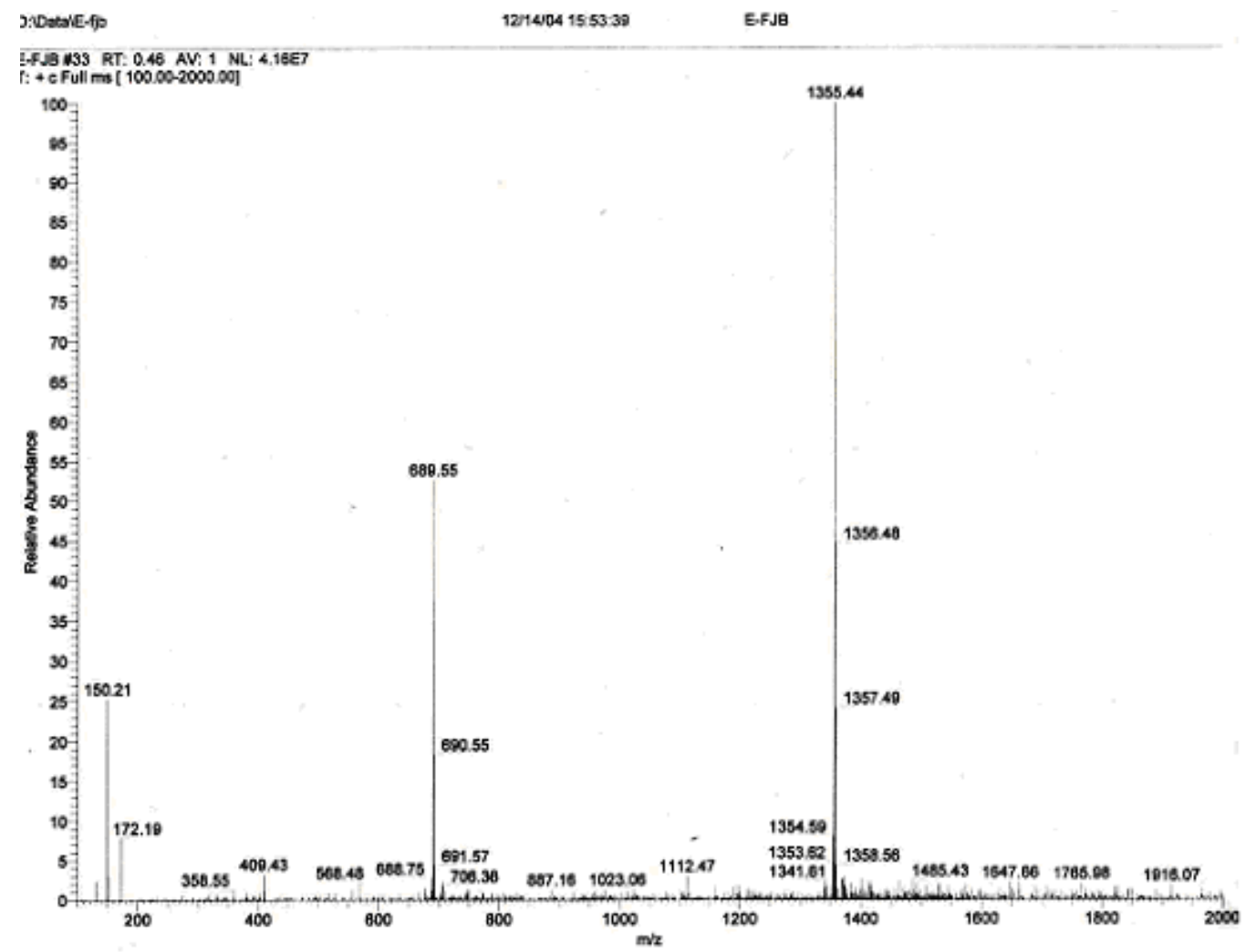


S39. ${ }^{1} \mathrm{H}$ NMR $\left(\mathrm{C}_{5} \mathrm{D}_{5} \mathrm{~N}, 600 \mathrm{MHz}\right)$ Spectrum of (20S)-Niga-ichigoside F1 (6)

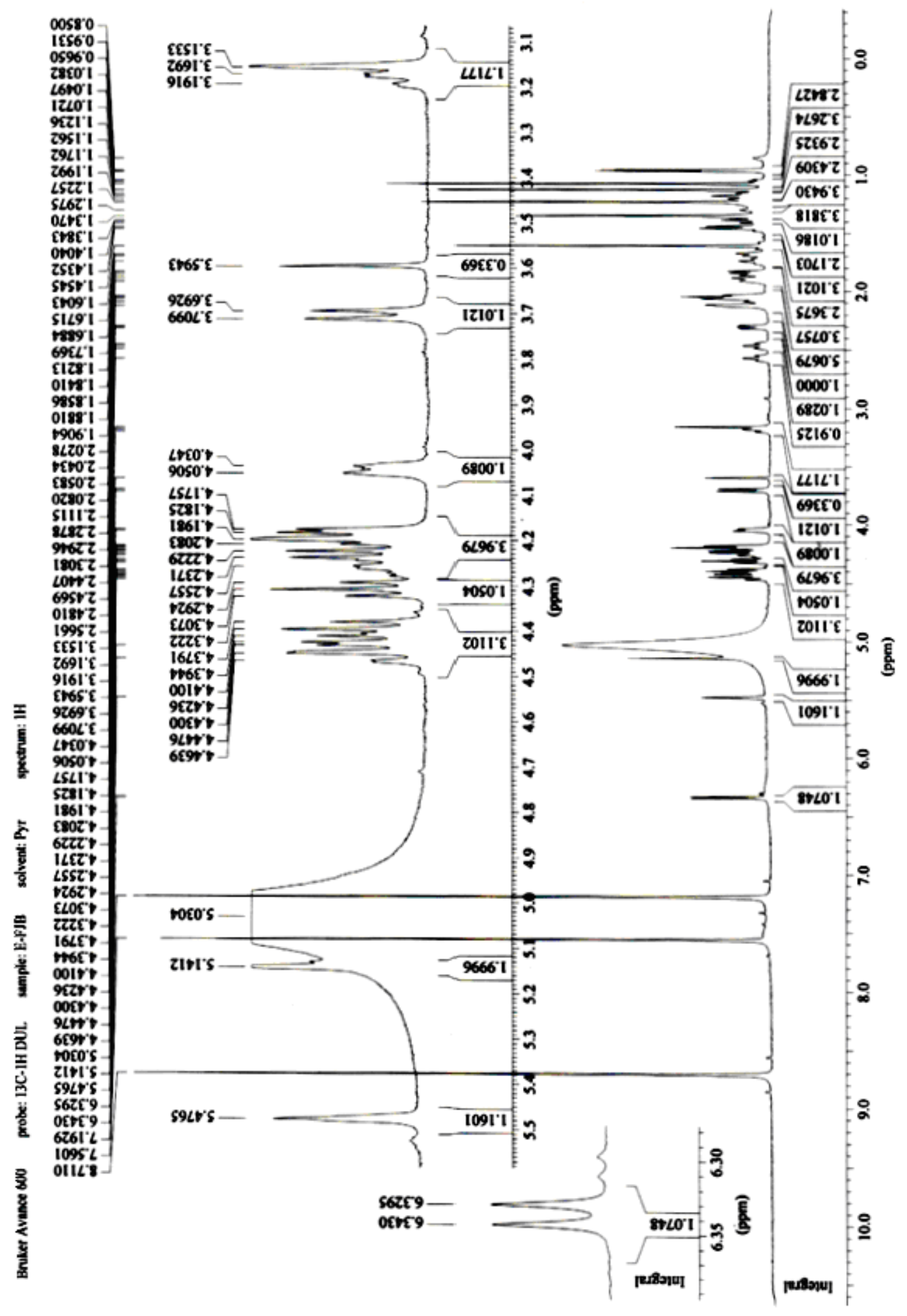


S40. ${ }^{13} \mathrm{C}$ NMR $\left(\mathrm{C}_{5} \mathrm{D}_{5} \mathrm{~N}, 150 \mathrm{MHz}\right)$ Spectrum of (20S)-Niga-ichigoside F1 (6)

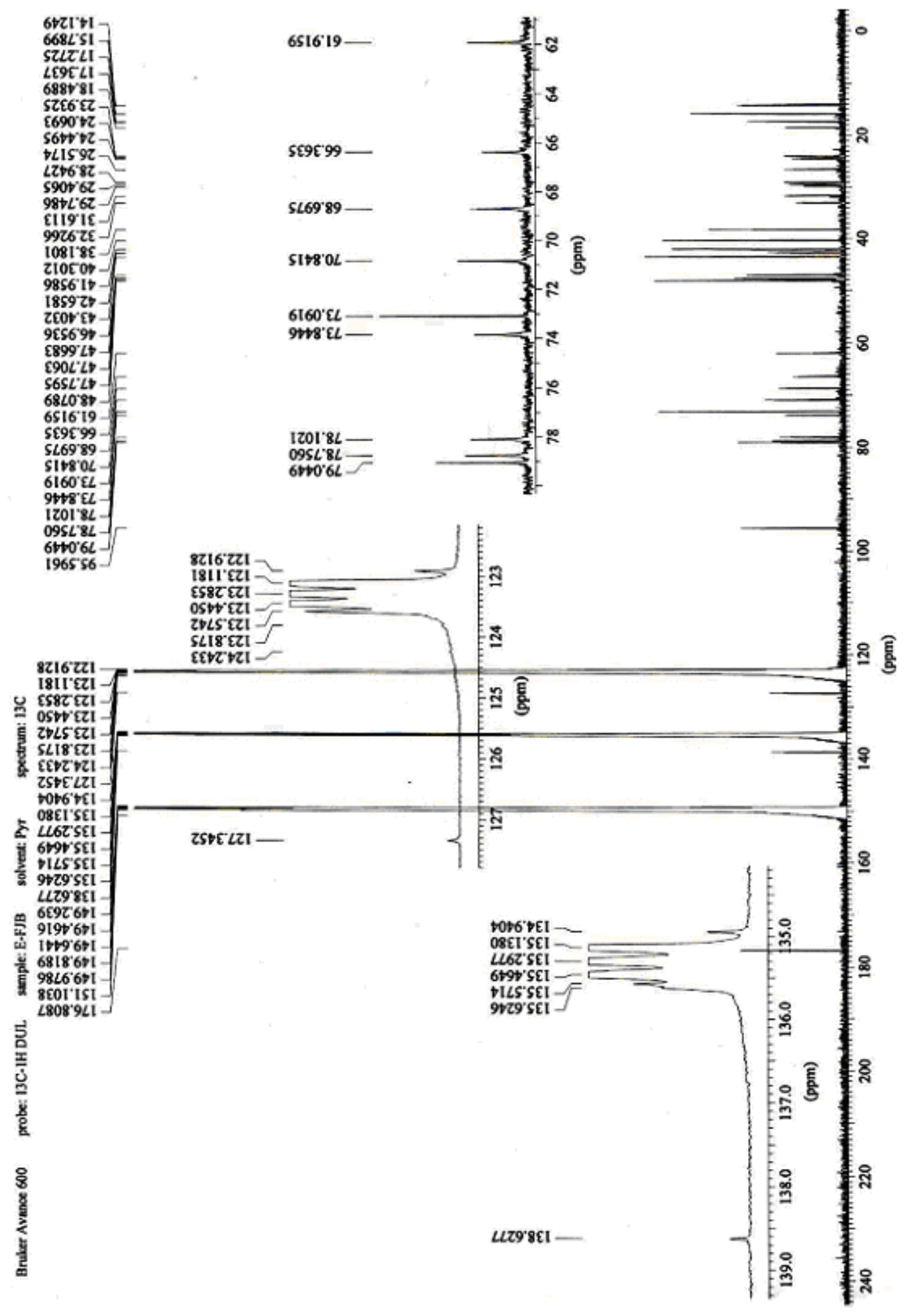


S41. HSQC Spectrum of (20S)-Niga-ichigoside F1 (6)

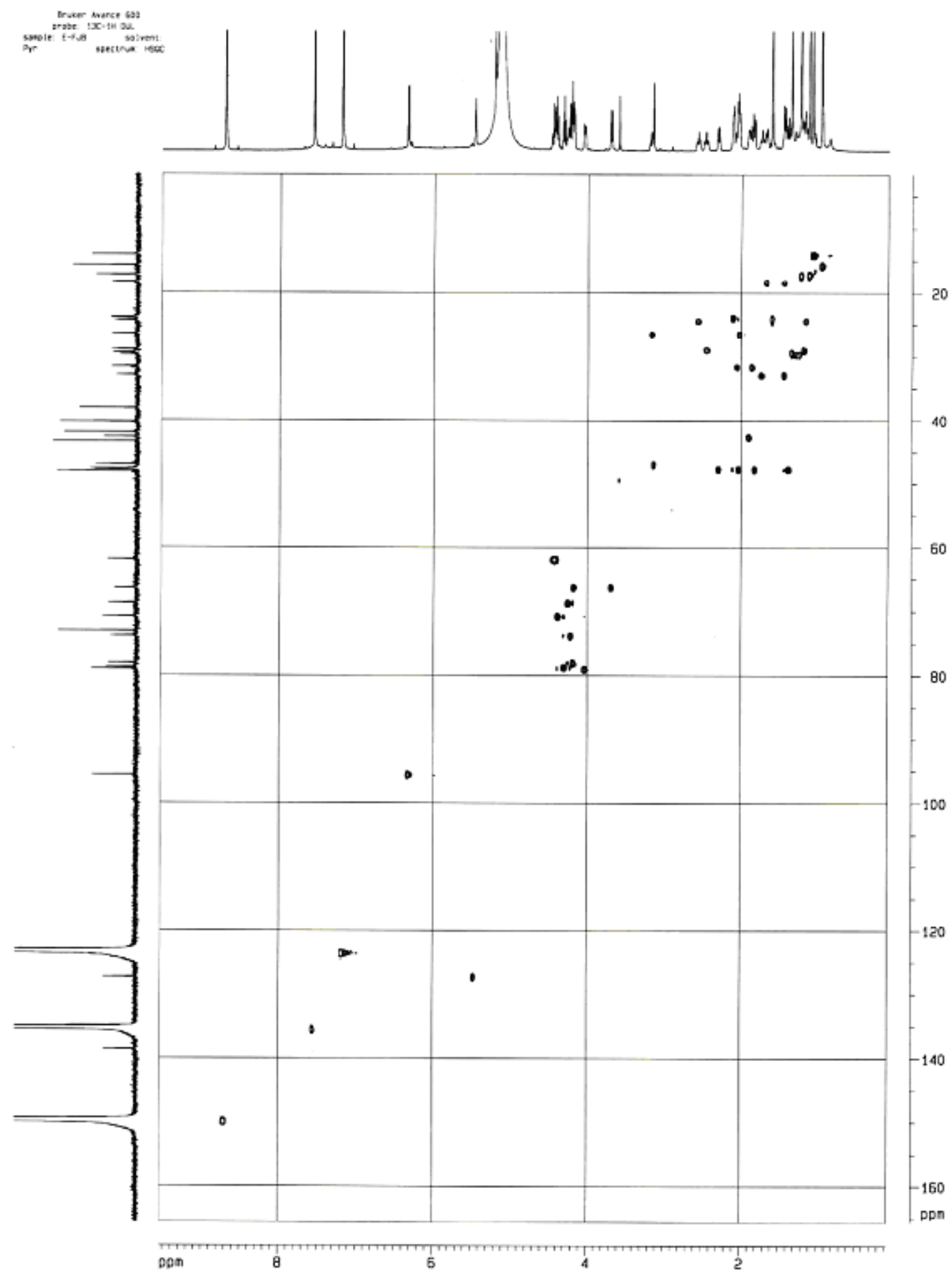


S42. HMBC Spectrum of (20S)-Niga-ichigoside F1 (6)

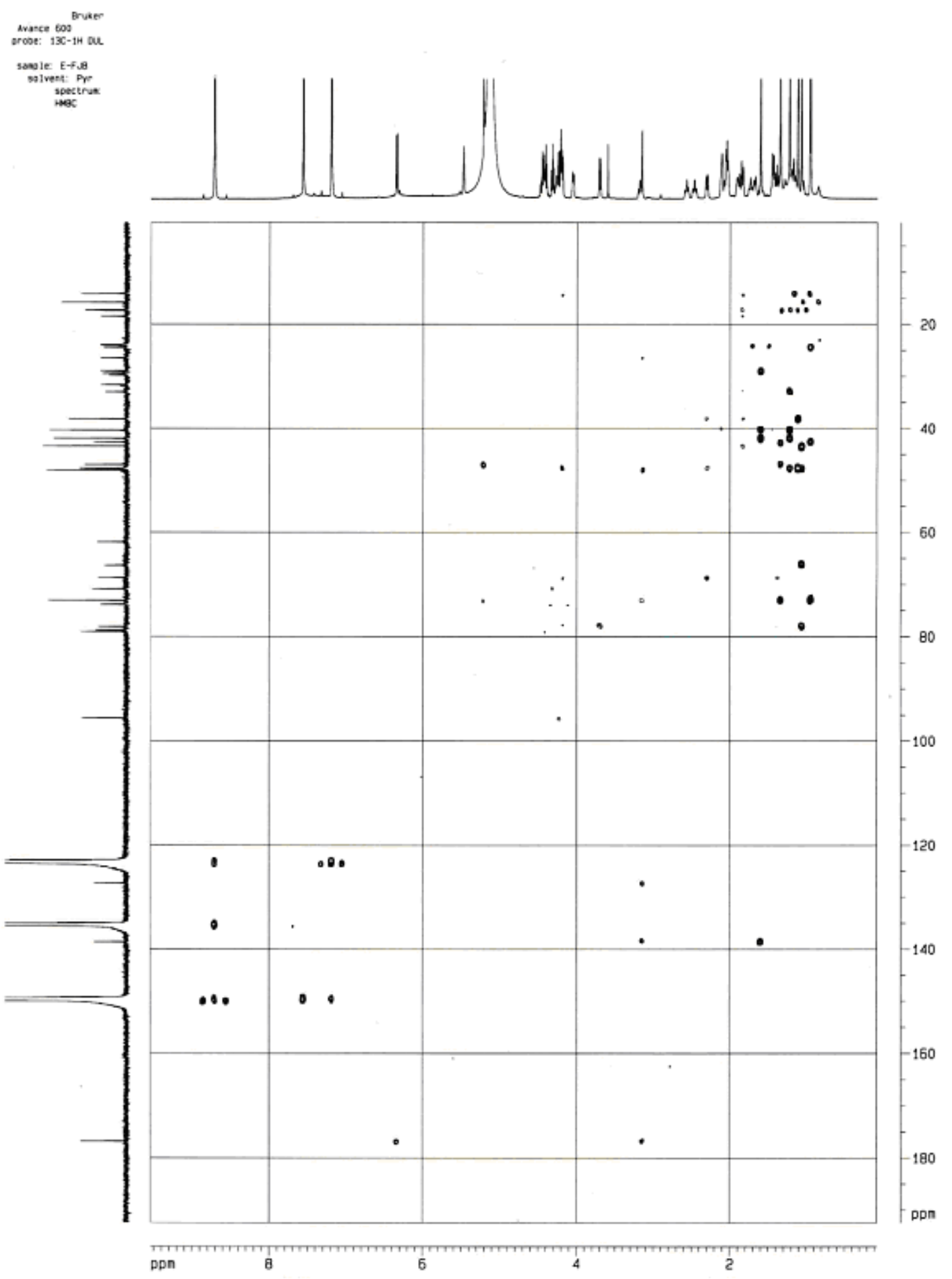


S43. NOESY Spectrum of (20S)-Niga-ichigoside F1 (6)
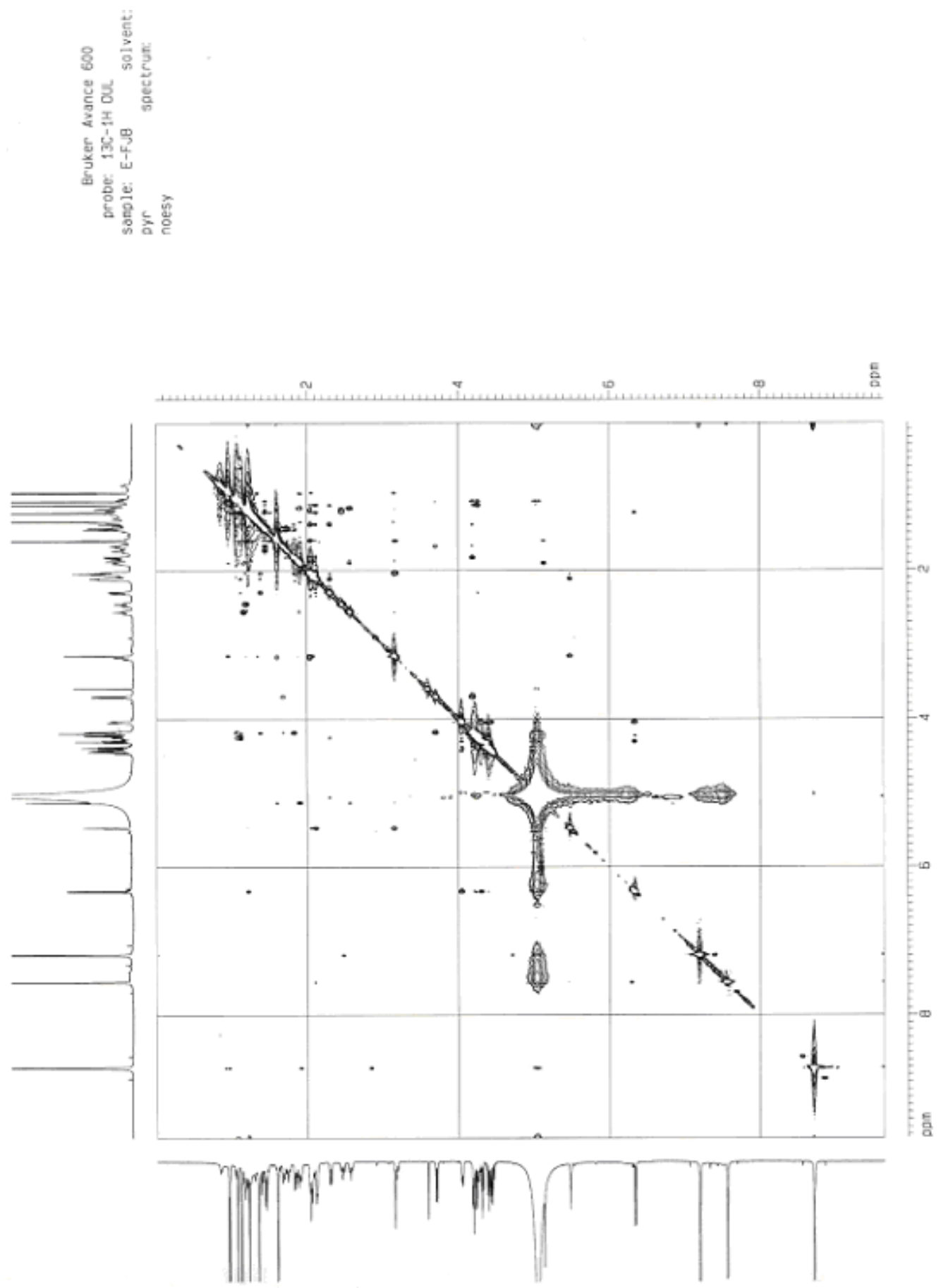